EFFECT OF REDUCED INDUSTRIAL PUMPAGE ON THE MIGRATION OF

DISSOLVED NITROGEN IN AN OUTWASH AQUIFER AT OLEAN,

CATTARAUGUS COUNTY, NEW YORK

By Marcel P. Bergeron

U.S. GEOLOGICAL SURVEY

Water-Resour ces Investigations Report 85-4082

Prepared in cooperation with

NEW YORK STATE DEPARTMENT OF ENVIRONMENTAL CONSERVATION

It haca, New York 


\section{UNITED STATES DEPARTMENT OF THE INTERIOR \\ DONALD PAUL HODEL, Secretary}

GE OLOGICAL SURVEY

Dallas L. Peck, Director

For additional information write to:

U. S. Geological Survey

$521 \mathrm{~W}$. Se neca Street

It haca, New York 14850

(607) 272-8722
Copies of this report may be purchased from:

U.S. Geological Survey Books and Open-File Reports

Federal Center, B1dg. 41

Box 25425

Denver, Colo. 80225

(303) $236-7476$ 


\section{CONTENTS}

Abstract . . . . . . . . . . . . . . . . . . . . . . . .

Introduction . . . . . . . . . . . . . . . . . . . . . . . . .

Purpose and scope . . . . . . . . . . . . . . . . . . . .

Acknowl edgments . . . . . . . . . . . . . . . . . . . . . .

Hyd roge ologic setting. . . . . . . . . . . . . . . . . . . . . .

Geology . . . . . . . . . . . . . . . . . . . . . . . .

Extent and thickness of shallow outwash aquifer . . . . . . . . .

Area 1... . . . . . . . . . . . . . . . . . . . . . .

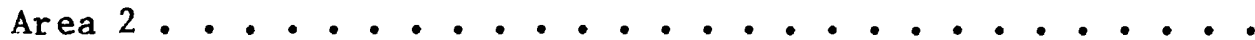

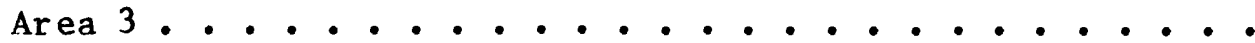

Area 4 . . . . . . . . . . . . . . . . . . . . . .

Area 5. . . . . . . . . . . . . . . . . . . . . .

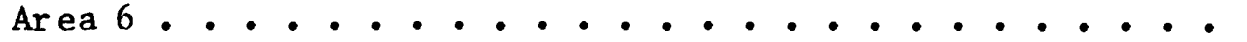

Area 7 . . . . . . . . . . . . . . . . . . . .

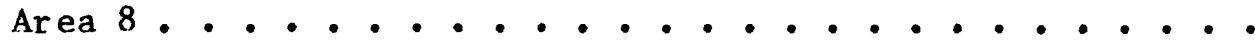

Area 9. . . . . . . . . . . . . . . . . . . . . .

Ar ea 10. . . . . . . . . . . . . . . . . . . . . . .

Area 11. . . . . . . . . . . . . . . . . . . . . . .

Hyd rology of shallow outwash aquifer . . . . . . . . . . . . . . . .

Ground-water f1 ow patterns. . . . . . . . . . . . . . . .

Hydraulic characteristics . . . . . . . . . . . . . . . .

Pump age . . . . . . . . . . . . . . . . . . . . . . .

Sources of recharge . . . . . . . . . . . . . . . . . . . .

Ot her ground-water discharges . . . . . . . . . . . . . . . .

Water-level fluctuations. . . . . . . . . . . . . . . . .

Distribution of nitrogen compounds in the aquifer system . . . . . .

Digital model analysis of the aquifer system . . . . . . . . . . . .

Mo del selection and design. . - . . . . . . . . . . . . . .

Conceptual model. . . . . . . . . . . . . . . . . . . .

Model layering . . . . . . . . . . . . . . . . . . .

Vertical leakance between layers . . . . . . . . . . . .

St ream seepage . . . . . . . . . . . . . . . . . . . . .

Boundary conditions. . . . . . . . . . . . . . . . .

St eady-state calibration. . . . . . . . . . . . . . . . . .

Parameter adjustment . . . . . . . . . . . . . . . . .

Results. . . . . . . . . . . . . . . . . . . . . . .

Effects of reductions of industrial pumpage. . . . . . . . . . . . . .

Effects of full and partial shutdown of the two industrial

we11 fields in North 01 ean and along Allegheny River. . . . . 31

Fu11 s hut down . . . . . . . . . . . . . . 31

Partial shutdown. . . . . . . . . . . . . 33

Effects of well-shutdown experiments on streamflow. . . . . . . 34

Ful1 shutd own .. . . . . . . . . . . . . . 34

Partial shutdown. . . . . . . . . . . . . 35

Effects of relocating industrial discharge from Twomile Creek . . 36

Summary and conclusions. . . . . . . . . . . . . . . . . . . 37

References cited . . . . . . . . . . . . . . . . . . . . . . 38 


\section{ILLUSTRATIONS}

Page

Figure 1. Map showing location of study area. . . . . . . . . . . 2

2. Geologic sections $A-A^{\prime}$ through $F-F^{\prime}$. . . . . . . . 6

3. Graphs showing water-level fluctuations in wells 7 and 14 during 1972-81 . . . . . . . . . . . . . 17

4. Geologic section $\mathrm{Al}-\mathrm{Al}$ ' through industrial park showing lithologic units, direction of ground-water flow, and nitrogen concentrations in September 1979 . . . . . . .

5. Maps showing average concentrations of nitrogen in ground water at and near industrial park in 1979:

A. In upper $50 \mathrm{ft}$ of aquifer. B. In lower $30 \mathrm{ft}$ of aquifer. 20

6. Generalized geologic section showing aquifer layering used in digital model. . . . . . . . . . . . . . . .

7. Graph showing simulated water-level recovery after full shutdown of oil company wells in North Olean, at two magnitudes of specific yield and storage coefficient. . . .

\section{TABLES}

Table 1. Seepage losses and gains indicated by streamflow me asurements:

A. Twomile Creek, summer 1977 . . . . . ....... 14

B. Ole an Creek, summer 1978 . . . . . . . . . . . 15

2. Range of final vertical hydraulic conductivity for streambed and conductance values for modeled stream reaches. . . . .

3. Comparison of measured 1981 water levels with water levels resulting from simulation of 1981 conditions . . . . .

4. Estimated and calibrated steady-state seepage rates for modeled stream reaches . . . . . . . . . . . . .

5. Water budget of the calibrated steady-state model simulating average hydrologic conditions of March-November 1981 . . .

6. Water budget for the calibrated steady-state model and model experiments. . . . . . . . . . . . . . •

7. Model-generated seepage rates under present conditions, four pumping schemes, and relocation of industrial discharge. • • 


\section{PLATES}

(in pocket)

Plates 1-4. Maps of olean and vicinity showing:

1. Areas of uniform aquifer geometry.

2. Water-table altitude and directions of ground-water f1ow, Novembe $\mathrm{r} 4-5,1981$.

3. Distribution and average annual rates of major municipal and industrial pumpage in 1981.

4. St reamflow-measur ement sites on Twomile Creek and Ole an Creek during 1977 and 1978 and designation of stream reaches simulated in digital model.

5. Map of modeled area showing finite-difference grid and boundary conditions.

6-7. Maps showing calibrated transmissivity distribution:

6. In model layer 1 .

7. In mode 1 layer 2.

8-9. Maps showing mode1-generated water levels under 1981 pumping conditions and deviation from average 1981 water levels:

8. In mode1 layer 1.

9. In mode 1 layer 2 .

10-14. Maps showing water-leve1 altitude in model layer 2 during simulated pumping schemes:

10. Total shutdown of the fertilizer company's purge we 11 and the oil company's well fields in North olean and along the Allegheny River.

11. Partial shutdown of oil company's we 11 fields in North olean and along the Allegheny River and a full shutdown of the fertilizer company's purge we 11.

12. Full shutdown of the oil company's wells in North olean and along the Allegheny River.

13. Relocation of the fertilizer company's discharge from Twomile Creek to Allegheny River.

14. Simulated relocation of the fertilize $r$ company's discharge from Twomile Creek to Allegheny River. 


\section{CONVERSION FACTORS AND ABBREVIATIONS}

Factors for converting the inch-pound units used in this report to metric (International System) units are shown below.

\section{$\underline{\text { Multiply }}$}

inch (in)

foot $(f t)$

$\operatorname{mile}(\mathrm{mi})$

foot per $\mathrm{mile}(\mathrm{ft} / \mathrm{mi})$

inch per year (in/yr)

square mile $\left(\mathrm{mi}^{2}\right)$

cubic foot per second $\left(\mathrm{ft}^{3} / \mathrm{s}\right)$

ga1lon per minute (gal/min)

million gallons per day (Mgal/d)

feet squared per day $\left(f t^{2} / d\right)$

foot per day $(f t / d)$

degree Fahrenheit
By

25.4

0.3048

1.609

0.1894

25.40

2.59

28.32

0.06309

43.81

0.0929

0.3048

$5 / 9\left({ }^{\circ} \mathrm{F}-32\right)$
To Obtain

millimeter $(\mathrm{mm})$

meter ( $\mathrm{m}$ )

kilometer $(\mathrm{km})$

meter per kilometer $(\mathrm{m} / \mathrm{km})$

millimeter per year (mm/yr)

square kilometer $\left(\mathrm{km}^{2}\right)$

liter per second $(\mathrm{L} / \mathrm{s})$

liter per second $(\mathrm{L} / \mathrm{s})$

liter per seond $(\mathrm{L} / \mathrm{s})$

meters squared per day $\left(\mathrm{m}^{2} / \mathrm{d}\right)$

meter per kilometer $(\mathrm{m} / \mathrm{km})$

deg ree Celsius 


\title{
EFFECT OF REDUCED PUMPAGE ON THE MIGRATION OF DISSOLVED NITROGEN IN AN OUTWASH AQUIFER AT OLEAN, CATTARAUGUS COUNTY, NEW YORK
}

\author{
By
}

Marce1 P. Bergeron

\begin{abstract}
Ground water beneath an industrial park at 01ean, N.Y., contains nitrogen compounds in concentrations that in 1979 ranged from 100 milligrams per liter ( $\mathrm{mg} / \mathrm{L}$ as $\mathrm{N}$ ) to $1,840 \mathrm{mg} / \mathrm{L}$ as $\mathrm{N}$. Continuous pumping from seven industrial production wells and a purge well at the site has created a cone of depression within which all nitrogen compounds are contained and are thus prevented from migrating to nearby private and municipa1-supply we11s. Water from three of the production we1ls and the purge we11 contains 98 percent of al1 nitrogen removed at the well field. This water is used by a fertilizer plant in the industrial park for cooling and is continuously discharged to Twomile Creek--a sma11 intermittent stream in West olean.
\end{abstract}

A quasi-three dimensional two-1ayer digital ground-water flow mode 1 was developed to evaluate the effects of industrial and municipal pumping on the migration of the nitrogen-bearing ground water in the shallow outwash aquifer. The aquifer system consists of extensive coarse sand and grave1 outwash that lies mostly within the top 100 feet of unconsolidated deposits beneath the floors of major valleys. In some areas, fine-grained lacustrine or till deposits confine deeper outwash.

Several hypothetical schemes to minimize pumping while containing the nitrogen-bearing water were simulated to predict changes in the rate and direction of movement of contaminated ground water. Simulation of a full shutdown of the industrial we 11 field and the purge we11 indicated that ground water flowing laterally from the area of contamination would migrate south to southwestward for about 5 years before reaching the municipal we11 field along the Allegheny River. Nitrogen concentrations of ground water arriving at the municipal well field would probably be significantly lowered through dilutior, mechanical dispersion, and adsorption.

With only the purge we11 in operation, ground water along the southwestern edge of the containment area could probably escape but would require 8 to 9 years to migrate to the municipal well field.

Relocating the current industrial discharge from Twomile Creek to Allegheny River would cause water levels near Twomile Creek to decline an additional 1 to $3 \mathrm{ft}$, but operation of the industrial-production wells and the purge well would keep the contaminated ground water within the cone of depression. The loss of infiltration from Twomile Creek would cause streamflow in the Allegheny River and 0lean Creek to decline by an additional 0.45 and 0.05 cubic feet per second, respectively. 


\section{INTRODUCTION}

The U.S. Geological Survey, in cooperation with the New York State Department of Envi ronmental Conservation, has been investigating the effects of industrial and municipal development of a shallow glacial outwash aquifer at Olean, N.Y., in southeastern Cattaraugus County (fig. 1). The focus of these studies has been an area at and near an industrial park in north 0lean, where large amounts of nitrogen compounds, including ammonia and urea, are manufactured for use in fertilizer and animal feed.

Since 1969, high concentrations of nitrogen, primarily ammonia and nitrate, have been detected in the shallow aquifer at the industrial park. Although no single predominant source has been identified, the high concentrations have been attributed to various spills and leaks of fertilizer, process compounds, and wastewater that have infiltrated the soil and the aquifer system in this area over the years (Randa11, 1977).

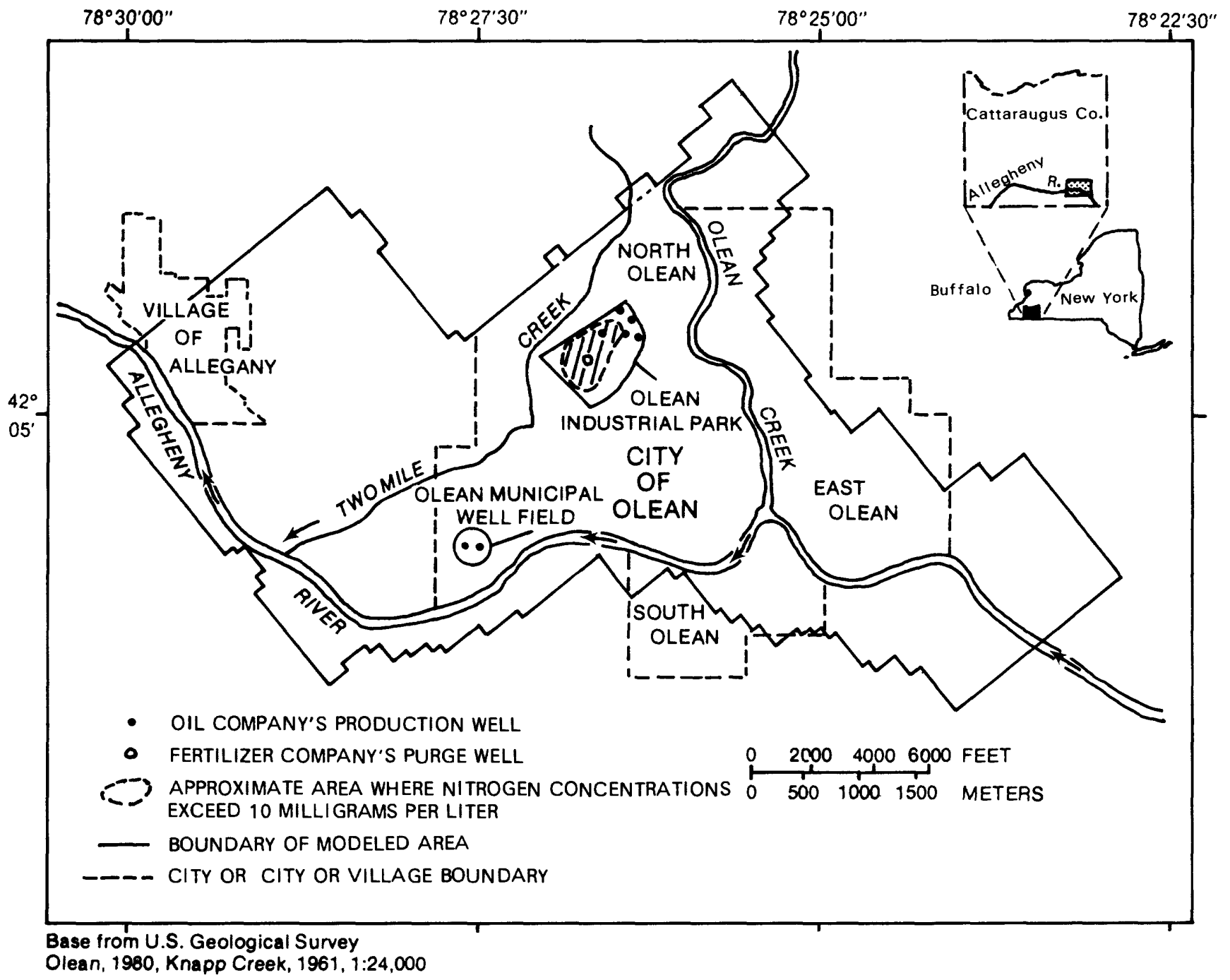

Figure 1.--Location of study area. 
During the 1970's and early 1980's, pumping at an oil company's we 11 field in the park maintained a cone of depression 20 to $30 \mathrm{ft}$ deep at the center and several thousand feet in diameter. In 1978, in an effort to acce1erate the rate of nitrogen removal from the aquifer, a fertilizer company installed a well capable of pumping $1 \mathrm{Mgal} / \mathrm{d}$ from the aquifer near the area of highest nitrogen concentration. This well has been referred to as the "purge we11." As a result, all nitrogen-bearing ground water has flowed toward the center of the well field and the "purge well," where the water is eventually withdrawn. This pumping has contained nitrogen-bearing ground water within the complex and has prevented it from migrating to nearby private and municipal water-supply wells.

A continuing concern of State and local authorities has been that a decrease in industrial water demand or a shutdown of industrial operations at the park would reduce ground-water withdrawals below current leve1s. The hydrologic effects of a major decrease could impair the contaminant-containment efforts at the park and allow nitrogen-bearing ground water to migrate laterally to nearby private and municipal water supplies.

Another concern has been the discharge of pumped water to local streams. Water from three production wells of the oil company and from the purge well of the fertilizer company, which contains 98 percent of all nitrogen removed from the complex (Hydro Systems, 1980, p. 31), is used by the fertilizer company for cooling and is subsequently discharged to Twomile Creek, a small stream west of the complex (fig. 1). At present, ammonia concentrations in the discharge exceed a State standard of $2 \mathrm{mg} / \mathrm{L}$ for the stream. Consequently, a relocation of the discharge from Twomile Creek to the Allegheny River, where higher flows can assimilate the ammonia concentrations, is under consideration. The resulting loss of streamflow will, however, affect the loca 1 ground-water regime.

In September 1980, the Geological Survey, in cooperation with New York State Department of Environmental Conservation, undertook a 2-year study to evaluate the hydraulic effects of industrial and municipal development on the migration of nitrogen-bearing ground water in the shallow aquifer. As a part of that study, the Survey developed a ground-water flow model of the aquifer system in 0lean to (1) simulate ground-water flow and ground-water/surfacewater interaction within the shallow aquifer, and (2) help evaluate the hydro1 ogic effects of reduced pumpage at the 0lean Nitrogen Complex. The predicted changes in ground-water levels and resulting patterns of flow were then used to estimate the direction. and the rate at which the nitrogen-bearing ground water would move in the aquifer. The model was also used to evaluate the hydrologic effect of relocating the point of industrial discharge from Twomile Creek to the Allegheny River.

\section{Purpose and Scope}

This report (1) describes the hydrogeologic setting at the industrial park at 0lean, including the geology, aquifer characteristics, and ground-water flow patterns; (2) the distribution of nitrogen compounds in ground water at the site; and ( 3 ) the effects of reduced industrial withdrawals on the movement of nitrogen compounds in ground water from the site. 
The effects of reduced ground-water withdrawals were assessed by means of the digital flow model. This report describes the development, calibration, and application of the model, and presents the results of four simulated pumping experiments to evaluate changes in ground-water levels, ground-water flow patterns, and ground-water recharge or discharge to local streams. Also included are estimates of traveltime required for nitrogen-bearing ground water to reach a nearby municipal well field and results of a simulated relocation of industrial discharge from Twomile Creek to Allegheny River.

\section{Acknowledgments}

The author extends thanks to Daniel King and Robert Speed of the New York State Department of Environmental Conservation, Edward Anderson of C.F. Industries, and John Hare and John Pfeiffer of Felmont 0il Co. for sharing and collecting data during the investigation. The author also thanks Allan D. Randall of the U.S. Geological Survey for his contributions in initial investigations and in development of a ground-water flow model that provided the basis for the model described herein.

\section{HYDROGEOLOGIC SETTING}

0lean is in southeast Cattaraugus County, about $60 \mathrm{mi}$ southeast of Buffalo (fig. 1). Principal communities in the area include the city of olean and village of Allegany. The area lies within the glaciated Allegheny section of the Appalachian Plateau physiographic province and is drained by the A1 legheny River and several perennial and intermittent streams. The two most important tributaries in this investigation are 0lean Creek, a major perennial stream east of the Olean Nitrogen Complex, and Twomile Creek, a minor intermittent stream west of the complex (fig. 1 ).

\section{Geology}

During the Pleistocene Epoch, continental ice sheets covered most of New York but did not advance beyond the Allegheny River valley in western New York (MacClintock and Apfel, 1944). Consequently, unconsolidated sediments within the Allegheny River and Olean Creek valleys (fig. 1) near Olean were deposited by glacial as well as postglacial processes. Much of the sediment was deposited either directly by ice or by meltwater. These two valleys are deeply incised in bedrock, which consists of gray and black shale and interbedded gray siltstone and sands tone of the Conneaut and Conewango Groups of Late Devonian age (Rickard and Fisher, 1970). These rocks dip gently to the south and crop out in upland areas around olean.

Unconsolidated sediments cover nearly all of the bedrock near olean. These deposits are thin in the uplands and thick in the valleys. The Al legheny River and Olean Creek valleys contain sediments 150 to $300 \mathrm{ft}$ thick in the study area. The lower part of the valley fill is predominantly clay and silt, presumably deposited in an extensive lake, or lakes, ponded in front of the ice. The shallower material consists of till and stratified drift that reaches altitudes of 1,500 to $1,800 \mathrm{ft}$ above sea level; these materials were deposited by an ice tongue extending down olean Creek. Remnants of an end moraine from the glaciation are found along the valley wall south of the 
Al legheny River at 01 ean and Allegany. Modern stream val leys are generally incised into the glacial deposits and contain 10 to 30 feet of postglacial alluvium that typically consists of silt overlying sand and gravel.

The glacial and postglacial sediment on the valley floors of the olean area consist mainly of sandy gravel and sand at shallow depths ( 80 to $100 \mathrm{ft}$ ) through which water can flow readily. These deposits constitute the single most important aquifer locally and the only potential source for large groundwater supplies. The aquifer is tapped by many industrial and municipal we1ls that obtain several hundred gallons per minute.

The shale, siltstone, and sandstone bedrock is also a local source of ground water near olean. However, it is much less permeable than sand and grave 1, and yields are adequate only for domestic we11s. The movement of water in bedrock is not discussed further herein, but Frimpter (1974, p. 22-23) describes in some detail ground-water flow in bedrock within the Al legheny River basin.

\section{Extent and Thickness of Shallow Outwash Aquifer}

The sand and gravel deposits that generally lie at depths of less than $100 \mathrm{ft}$ make up the principal aquifer in Olean. However, the aquifer is not uniformly thick nor continuous. Ten areas of uniform aquifer thickness can be defined from a review of available we 11 logs, test-boring logs, water-level records, and topography in and near 0lean. Locations of these areas are shown in plate 1; the stratigraphic relationships in these areas are shown in geo$\operatorname{logic}$ sections $A-A^{\prime}$ through F-F' (fig. 2). Descriptions of the areas follow.

\section{Area 1}

This area, which is in the northwestern part of the village of Allegany, is dominated by ice-contact deposits that form an extensive terrace that ranges in altitude from 1,430 to $1,520 \mathrm{ft}$. Test borings about $1,500 \mathrm{ft}$ north of Midway Airfield indicate that the terrace is capped by as much as $30 \mathrm{ft}$ of til1. (See section D-D', fig. 2.) We11 records from 7 th Street in Allegany indicate that a sand and gravel unit extending to depths of 90 to $120 \mathrm{ft}$ below 1 and surface forms a water-table aquifer. Depth to water is generally about $100 \mathrm{ft}$. In areas of 1 ower altitude to the southeast and southwest of area 1 , surficial sand and gravel may directly overlie older sand and gravel that is continuous with the aquifer in area 1; alternatively, lateral flow between area 1 and adjacent areas may be restricted by a layer of till or clay.

\section{Area 2}

This area consists of a prominent topographic feature more than $1,480 \mathrm{ft}$ in elevation near Oak Hill Park in downtown 01 ean that is capped by pebbly and cobbly gravel. Records of several wells near the corner of West State and Union Streets indicate that the surficial gravel is separated from a lower aquifer by fine-grained sediments (see section E-E', fig. 2). Surficial sand and gravel in areas of lower altitude surrounding Oak Hill may be younger. If so, the aquifers beneath the hill may pinch out or dip beneath the surrounding younger material. The fine-grained sediments may form barriers to lateral flow around the margins of the hill. 


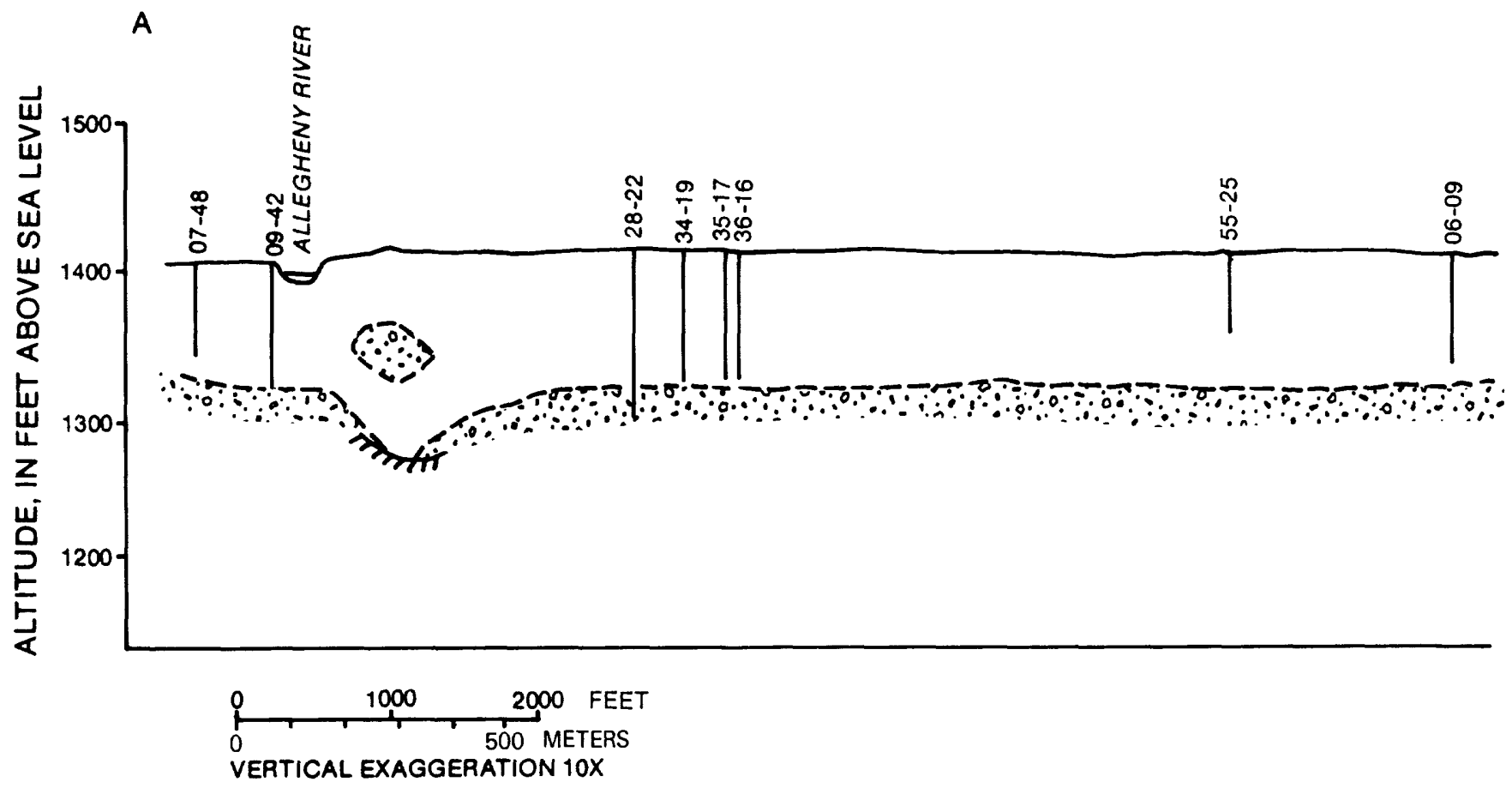

B

EXPLANATION
ஸे WELL AND NUMBER--Number is location,

in seconds of latitude and longtitude

GENERALLY PERMEABLE SAND OR

SAND AND GRAVEL

$\because 0$ GENERALLY IMPERMEABLE SILTY AND CLAYEY MATERIALS

TT SHALE BEDROCK

- - GEOLOGIC CONTACT

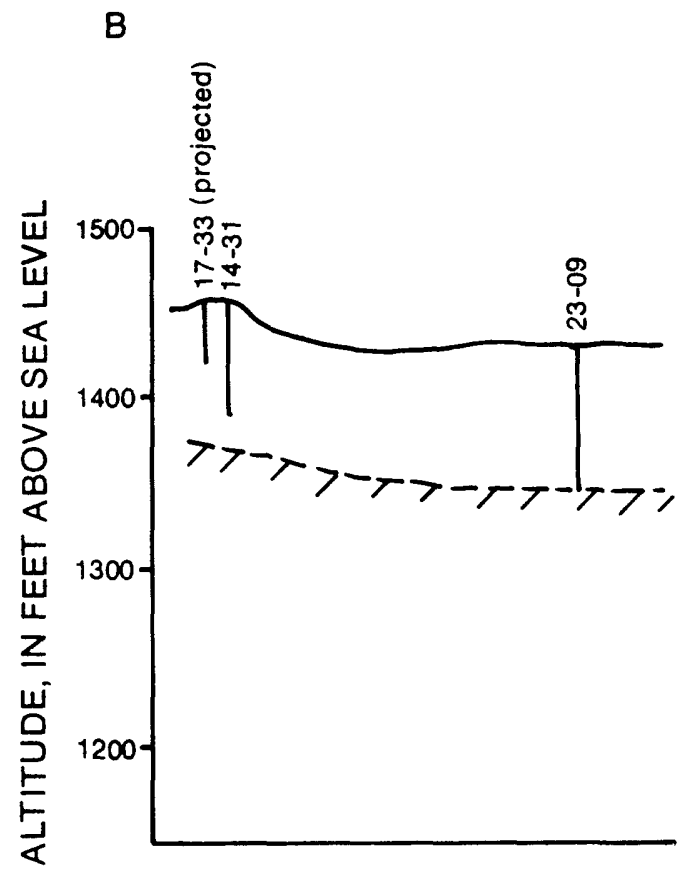

Figure 2.--Geologic sections (Locations are shown 

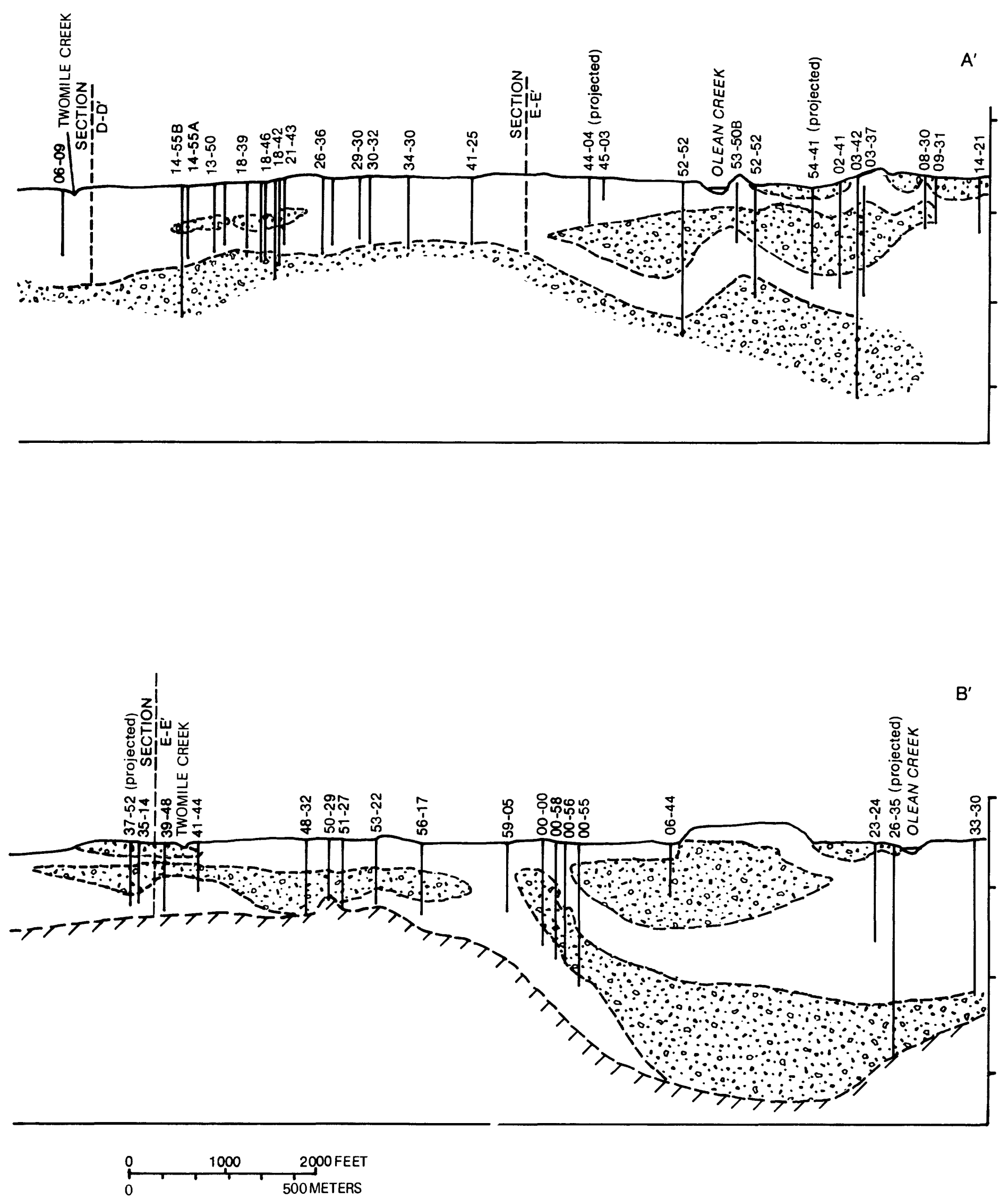

$A-A^{\prime}$ and $B-B^{\prime}$.

in pl. 1.) 


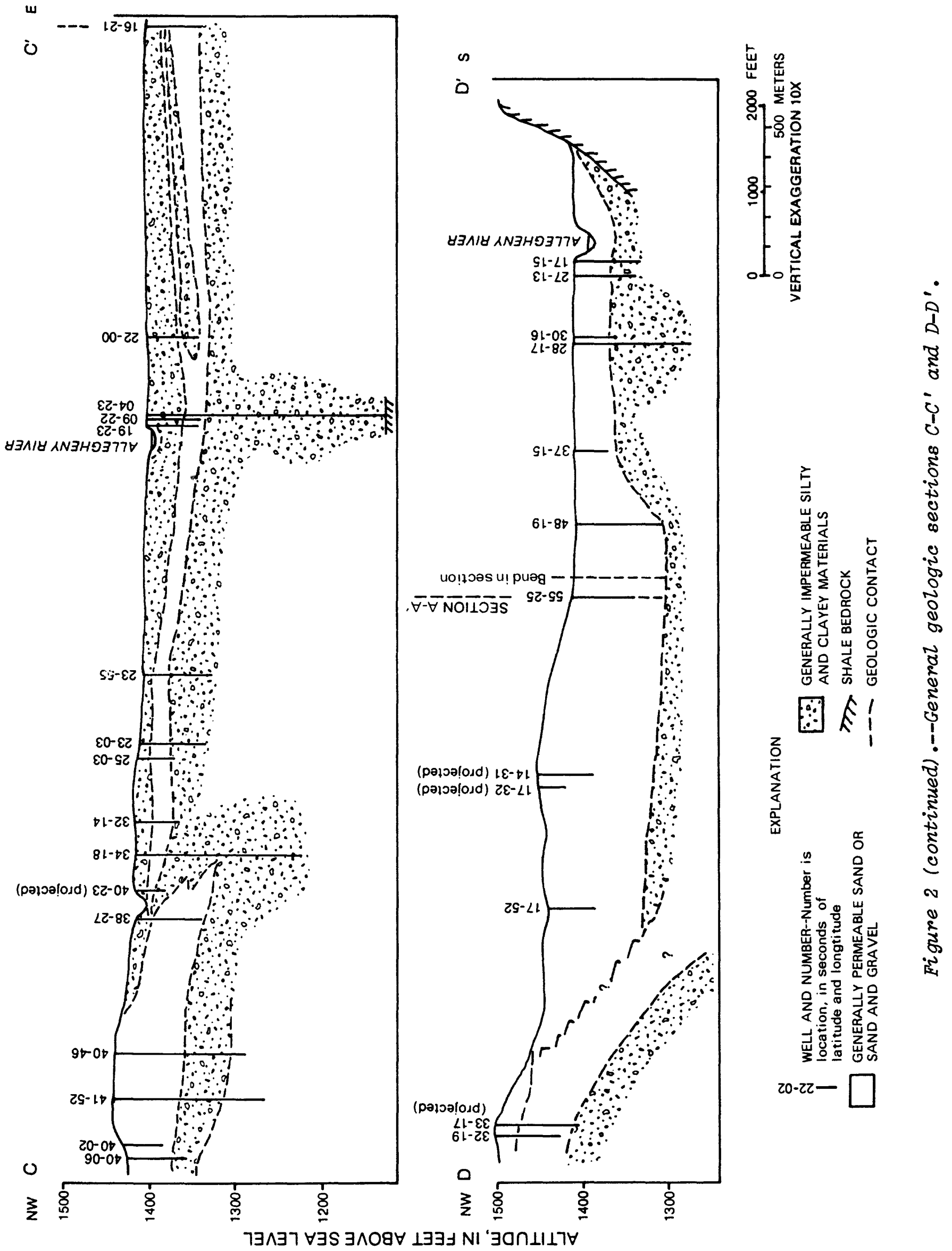




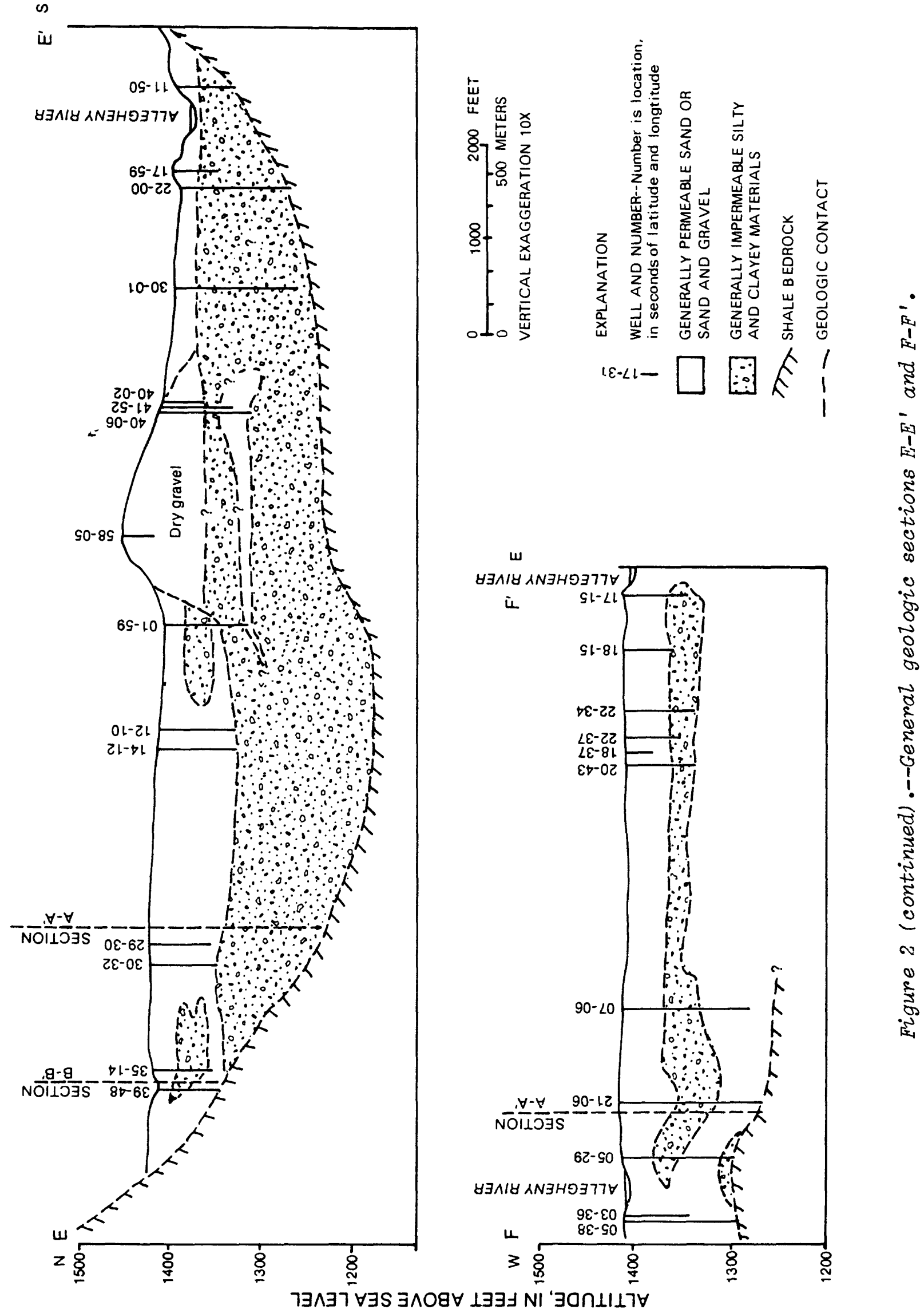


A surficial water-table aquifer 10 to 20 feet thick in North 01 ean and southward along 0lean Creek is indicated in logs of 45 holes. The aquifer is composed primarily of sand and gravel and is underlain by a continuous laye $r$ of lacustrine silt, clay, and (or) silty fine sand (see section A-A', fig. 2). Several holes that were drilled through the lacustrine layer penetrated sand and gravel beneath the surficial aquifer. The deeper sand and gravel is commonly reported to be silty or only moderately permeable. Water levels measured in a few deep wells within the cone of depression at the oil company's well field at the industrial park (fig. 1) we re lower than water levels in the shallow aquifer. These data indicate some correlation of this un it with the deep aquifer in area 6 , to the west.

Area 4

Test holes in area 4, in south 0lean, indicate a surficial sand and gravel unit ranging in thickness from $10 \mathrm{ft}$ near South Union St reet to about $40 \mathrm{ft}$ (30 ft saturated) near the western city limit. (See sections D-D' and E-E', fig. 2.) West of the city sewage-treatment plant, this unit constitutes a productive aquifer. No deeper aquifer is present in area 4.

\section{Area 5}

Logs of several test wells in area 5, along the Allegheny River just west of 0lean, indicate highly permeable surficial sand and gravel 40 to $60 \mathrm{ft}$ thick. A thin and perhaps discontinuous clay layer lies between this unit and a deeper, less permeable silty gravel that is $50 \mathrm{ft}$ or more thick. (See section $\left.A-A^{\prime}, f i g .2.\right)$

\section{Area 6}

An abundance of test wells and borings in this northwestern part of olean penetrate sand and gravel to a depth of about $80 \mathrm{ft}$. (See sections $A-A^{\prime}$ and E-E', fig. 2.) The lower $30 \mathrm{ft}$ of the aquifer is generally more permeable than the upper $50 \mathrm{ft}$, which tends to be silty. Several industrial production wells owned by the oil company are screened at the base of the aquifer and yield from about 500 to $1,000 \mathrm{gal} / \mathrm{min}$. Extensive thin lenses of silty clay that act as a semiconfining layer are identified at depths of 30 to $50 \mathrm{ft}$ in parts of area 6A. (See section A-A', fig. 2.) Water levels in some shallow wells indicate mounds of perched ground water in the upper part of the aquifer above the semiconfining layer.

Area 7

This broad area west of 0lean is hummocky. Permeable materials to a depth of about $80 \mathrm{ft}$ are indicated in well logs. (See section D-D', fig. 2.) 
Test borings and well logs in the valley east of olean to Weston Mills suggest a productive sand and gravel aquifer between the depths of 40 and 85 ft. (See section $C-C^{\prime}$, fig. 2.) Aquifer thickness ranges from $0 \mathrm{ft}$ along the north and south limits of the area to $40 \mathrm{ft}$ in the central part of the valley. Lenses of till, 10 to $20 \mathrm{ft}$ thick, are found within the aquifer at depths of 45 to $80 \mathrm{ft}$ in an area east of the olean city limits. The aquifer is overlain by a continuous unit of fine-grained materials that include recent alluvial deposits and till. Surficial fluvial sand and gravel generally ranging in thickness from 10 to $30 \mathrm{ft}$ thick along the Allegheny River is mentioned in several well logs.

\section{Area 9}

Areas in the aquifer system labeled as area 9 are not as well defined as in other localities. The aquifer thickness and geometry in these areas have been interpreted from a few available we 11 records and logs and by extrapolation from better defined areas.

Area 10

Ar ea 10, in East 0lean, has been mapped by Muller (1977) as hillside kame terraces that presumably contain some permeable materials. No information other than the landform was available to substantiate the map. Data from area 8 indicate that the confined aquifer in the central part of the valley pinches out as it approaches the north and south valley walls and is not hydraulically connected to these terraces.

Area 11

Upland areas bordering the major valleys (Allegheny River and olean Creek valleys) are readily identified from the topographic map. These areas are underlain by shale or siltstone bedrock covered with a thin mantle of till (north of the Allegheny River) or colluvium (south of the Allegheny River). Area 11 contains no significant stratified-drift aquifers.

\section{HYDROLOGY OF SHALLOW OUTWASH AQUIFER}

Al though the first 10 areas discussed in the previous section differ in thickness and geometry of the sand and gravel outwa sh deposits, collectively they form the shallow sand-and-gravel aquifer system that is the principal aquifer in olean. The system is bounded along the edges of the Allegheny River and 0lean Creek valleys by upland areas of shale and siltstone bedrock. At depth, the aquifer is underlain by thick lacustrine clay and silt deposits. Bedrock along the valley walls and clay and silt at depth are not significant sources of recharge or points of discharge for the shallow sand and gravel aquifer; consequently, these units represent major physical boundaries to the aqui fer system. 


\section{Ground-Water Flow Patterns}

Under nonpumping conditions, ground water in the shallow outwash aquifer would flow toward Olean Creek and the Allegheny River. Where ground-water levels intersect stream channels, ground water discharges to the stream channels and flows downvalley and out of the study area.

Periodic water-level measurements in 95 observation wells installed in 1981 were used to determine the direction of ground-water flow in the shallow aquifer. A potentiometric-surface map of the aquifer based on measurements made Nov. 16-17, 1981, is shown on plate 2. (The map is based principally on measurements made in wells completed in lower parts of the aquifer and consequently does not indicate the water-table configuration in localized areas where confining beds cause considerable vertical gradient and high water levels at shallow depths.) The pattern of ground-water movement shown in plate 2 suggests that continuous pumping of several 1 arge-capacity production wells has created several cones of depression and has altered the natural pattern of ground-water flow 1ocally. Most notable is the effect of pumping within we11 fields operated by the oil company in North olean and along the Al legheny River southwest of Olean.

Water levels near the production wells have been lowered as a result of pumping. Water levels near the center of the North 0lean well field ( $p 1.3$ ) in November 1981 are estimated to be $20 \mathrm{ft}$ below average. On several dates during 1970-75, when pumpage at North 01ean was reported at a high of 10 $\mathrm{Mgal} / \mathrm{d}$, water levels near the center of the well field were $10 \mathrm{ft}$ lower than in November 1981. In November 1981, water levels wi thin the Allegheny River well field, which is operated by the oil company, were as much as $10 \mathrm{ft}$ below the $r$ iver stage. As a result of these lowered water levels, ground water that normally would flow downvalley and toward the major streams now flows from all directions toward production wells to replace the pumped water (see p1. 2).

\section{Hydraulic Characteristics}

Hydraulic characteristics of the sand and gravel aquifer were estimated by analysis of pumping-test data from four wells and by applying specificcapacity data from 18 wells to methods described by Theis (1963, p. 332-336), and Brown (1963, p. 336-338). Transmissivity values calculated from these analyses are highly variable, ranging from 1,700 to $200,000 \mathrm{ft}^{2} / \mathrm{d}$. Most transmissivity values are between 10,000 and $60,000 \mathrm{ft}^{2} / \mathrm{s}$. Most hydraulicconductivity values (calculated by dividing the transmissivity by the average thickness of the aquifer at each we11) range from 300 to $1,500 \mathrm{ft} / \mathrm{d}$.

\section{Pumpage}

Ground water is discharged from the shallow sand and gravel aquifer by pumping. Most households and industries within the study area are serviced by the water utilities in the city of olean and the village of Allegany. Most of olean's ground-water withdrawal is in a field along the Allegheny River in 
southwe stern 0lean that is capable of producing about $1 \mathrm{Mgal} / \mathrm{d}$ or $1.55 \mathrm{ft} / \mathrm{s}$ (pl. 3). A municipal well field capable of producing $3.3 \mathrm{Mgal} / \mathrm{d}(5.1 \mathrm{ft} / \mathrm{s})$, developed by the City of Olean along the Allegheny River in East 0lean (pl. 3), has been out of use since February 1981, when several volatile organic compounds were detected in the water (Halgas, 1981). Olean derives the rest of its water supply $(4.5 \mathrm{Mgal} / \mathrm{d}$ or $7.0 \mathrm{ft} / \mathrm{s})$ from 01 ean Creek at a filtration plant in North olean. Al legany now derives its water supply from three wells in Al legany that together produce $0.8 \mathrm{Mgal} / \mathrm{d}$ or $1.24 \mathrm{ft}^{3} / \mathrm{s}(\mathrm{pl} .3)$.

Eight private firms obtain all or part of their water supply from ground water. The largest user is the oil company at the industrial park, which has developed several large-capacity production wells in three well fields in the vicinity of Olean. The company's well field in North Olean (p1.3) contains seven production wells, each capable of producing $1,000 \mathrm{gal} / \mathrm{min}$. Although this well field can produce $10.1 \mathrm{Mgal} / \mathrm{d}(15.6 \mathrm{ft} / \mathrm{s})$, wi thd rawals during 1981 amounted to only $4.5 \mathrm{Mgal} / \mathrm{d}\left(7.0 \mathrm{ft}^{3} / \mathrm{s}\right)$. Production from six wells in the company's well field along the Allegheny River southwest of Olean (p1. 3) in 1981 was estimated to be $8 \mathrm{Mgal} / \mathrm{d}\left(12.4 \mathrm{ft}^{3} / \mathrm{s}\right)$. Two additional wells in west olean produce $3.5 \mathrm{Mgal} / \mathrm{d}\left(5.4 \mathrm{ft}^{3} / \mathrm{s}\right)$, which raises the estimate of groundwater use by the company to $15.0 \mathrm{Mgal} / \mathrm{d}\left(23.3 \mathrm{ft}^{3} / \mathrm{s}\right)$. The remaining companies together pump $2.8 \mathrm{Mga} 1 / \mathrm{d}\left(4.3 \mathrm{ft}^{3} / \mathrm{s}\right)$. Pumpage from three of the oil company's we 11s (nos. 1, 2, and 6) in North 0lean and a purge well of the fertilizer company at the same site ( $f i g .1$ ) has been metered since 1980; pumpage from the other wells is estinated from the pump-rated capacities and hours of operation. The distribution and rates of major municipal and industrial pumpage for 1981 is shown on plate 3 .

\section{Sources of Recharge}

The primary source of recharge to the shallow aquifer is direct infiltration from precipitation. Monthly rainfall at olean is fairly constant throughout the year, ranging from $2.0 \mathrm{in}$. in February to $3.9 \mathrm{in}$. in July (National Oceanic and Atmospheric Administration, 1980, p. 4). However, recharge varies because evapotranspiration can reduce the amount of rainfall that infiltrates through the unsaturated zone. Normal monthly evapotranspiration at Allegany State Park has ranged from zero during December through March to 5 in. in July and totals about 23 in. annually (Harding and Gilbert, 1968, p. 32 ).

Initial estimates of areal recharge were derived by subtracting the theoretical monthly distribution of mean annual evapotranspiration loss from precipitation during 1981 . This analysis resulted in an areal recharge rate of $19 \mathrm{in} / \mathrm{yr}$.

Another source of recharge is seepage from the Allegheny River, 0lean Creek, Twomile Creek, and other small tributary streams. Seepage may occur naturally along the larger streams during periods of high surface-water runof during the late winter and early spring and during storms. Small tributary streans lose water at all times, mainly where the streams enter the valleys from upland areas. Seepage to the ground-water system may also be induced when nearby pumping lowers water levels beneath streams to below stream stage. This induced infiltration may permit we 11s to be pumped at much 1 arger rates than would otherwise be possible but also reduces flow in the stream. 
Ground-water levels were below stream stage in November 1981 (see plate 2) and on other dates of water-level measurement along Twomile Creek and some reaches of 01 ean $\mathrm{Cr}$ eek and Allegheny River near pumping centers. Hence, some induced infiltration from these streams to the aquifer was likely. Induced infiltration from Twomile Creek and 01 ean Creeks was estimated from streamflow measurements made by the Geological Survey during 1977 and 1978. F1 ow of Twomile Creek was measured at four sites on August 20-21 and September 1, 1977, and flow of 01 ean Creek was measured at three sites on July 21 and September 6, 1978. Locations of measurement sites are shown in plate 4; the discharge measurements and resulting seepage losses and gains along the two streams are summarized in tables $1 \mathrm{~A}$ and $\mathrm{IB}$. The measurements made on Twomile Creek on August 20-21, 1977, were probably less reliable than those made on September 1 because they were preceded by precipitation. The measurements of September 1 indicate streamflow losses of $0.33 \mathrm{ft}^{3} / \mathrm{s}$ between the fertilizer

Table 1A.--Seepage losses and gains indicated by streamflow measurements on Twomile Creek, summer 1977.

[Site locations shown on pl. 4.]

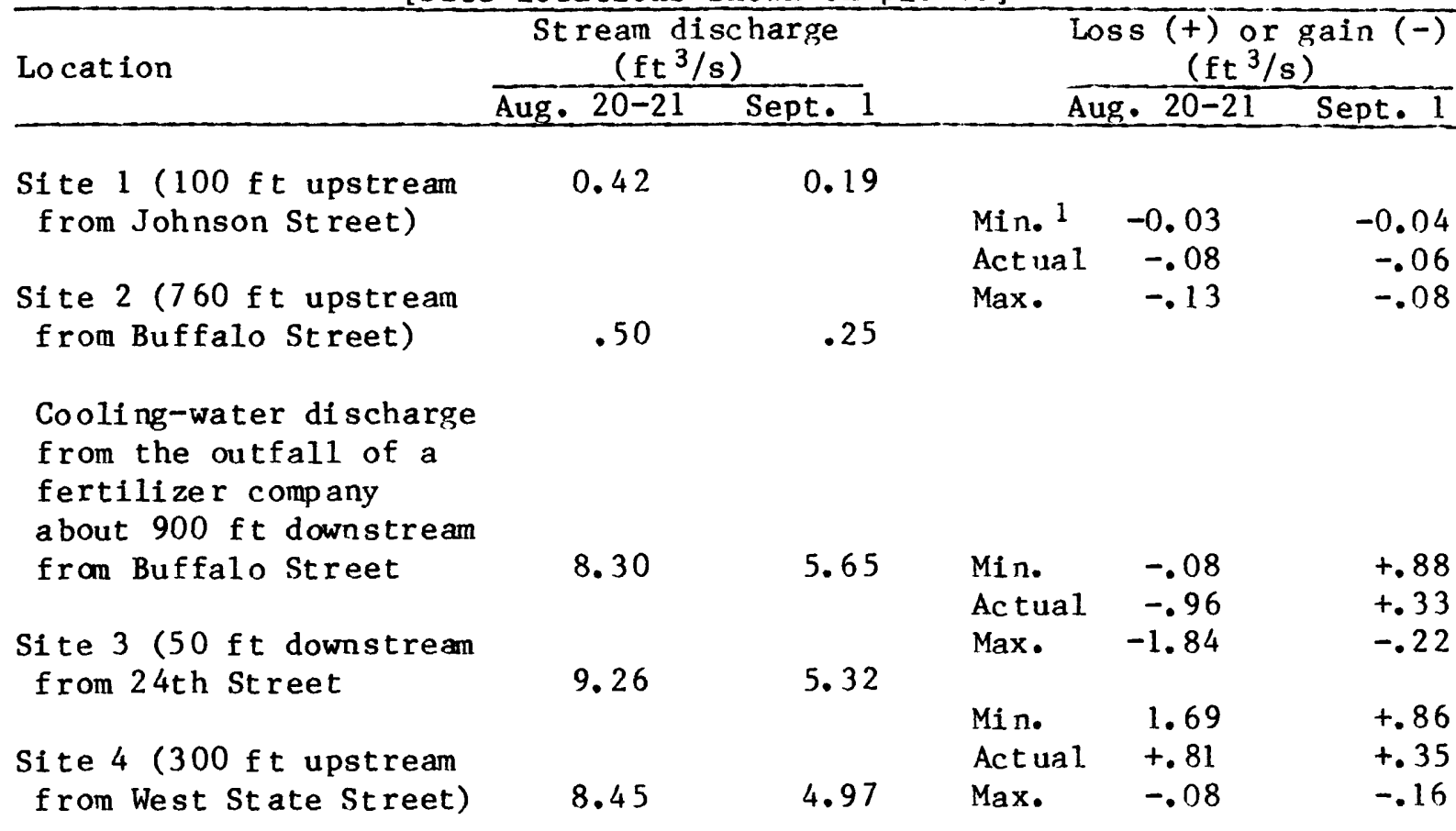

Antecedent conditions:

Aug. 20-21 Precipitation before 8 a.m. August 17; 1.31 in. Considerable rain earlier in August. Streanflow steady. Cooling-water discharge from fertilizer company steady.

Sept. 1 Precipitation before 8 a.m. August 30; 0.74 in. St reanf low steady • Cooling-water discharge from fertilizer company steady.

1 Actual rates of seepage are based on discharge measurements with no measurement error. Mi nimum and maximum values represent seepage reflecting $a \pm 5$-percent error in each discharge measurement. 
company's outfall and $24 \mathrm{th}$ Street (site 3 ) and $0.35 \mathrm{ft}^{3} / \mathrm{s}$ between $24 \mathrm{th}$ Street and West State Street (site 4). Di scharge measurements of 0lean Creek indicate an average 1 oss of about $0.91 \mathrm{ft}^{3} / \mathrm{s}$ between the 0lean city limit (site 5 in table 1B) and the railroad bridge (site 6) and little $(-0.44 \mathrm{ft} / \mathrm{s})$ or no gain $\left(0.02 \mathrm{ft}^{3} / \mathrm{s}\right.$ ) between the railroad bridge and the Main Street bridge (site 7).

No effort was made to quantify induced infiltration from the Allegheny River. Base flow of the Allegheny River is commonly between 200 and 400 $\mathrm{ft}^{3} / \mathrm{s}$. The error inherent in streamflow measurements of this magnitude inhibit the quantification of seepage in small reaches; therefore these 1 osses and gains we re de rived during model calibration.

$$
\begin{gathered}
\text { Table 1B.--Seepage losses and gains indicated by streanflow } \\
\text { measurements on Olean Creek, summer } 1978 .
\end{gathered}
$$

[Site locations shown on pl. 4.]

\begin{tabular}{lcc}
\hline Location. & $\begin{array}{c}\text { Stream discharge } \\
\left(\mathrm{ft}^{3} / \mathrm{s}\right)\end{array}$ & $\begin{array}{c}\text { Los }(+) \text { or gain }(-) \\
\left(\mathrm{ft}^{3} / \mathrm{s}\right)\end{array}$ \\
\cline { 2 - 5 } & July 21 Sept. 6 & July 21 Sept. 6 \\
\hline
\end{tabular}

Site 5 (330 ft upstream

from the intersection of the

Conrail railroad and Kents

Road, near Olean city limit)

Site 6 (230 ft upstream

from Conrail rail road bridge)

Withdrawa1 at city of 01ean

filtration plant

Di scharge from culvert, 0.2

miles upstream from Union

St reet bridge, right bank

Site 7 (180 ft upstream from

Main Street bridge)

Antecedent conditions:

July 21 - Precipitation, July 9, 0.23 in. Streamflow steady. The flow duration curve for the gaging station on the Allegheny River at Salamanca, N.Y., indicated the measured flow represented about a 90 percent flow duration.

Sept. 6 - Precipitation, Sept. 1, 2.04 in. Streamflow steady. The flow duration curve for the gaging station on the Allegheny River at Salamanca, N.Y., indicated the measured flow represented about a 89 percent flow duration.

1 Actual rates of seepage are based on discharge measurements with no measurement error. Minimum and maximum values represent seepage reflecting a \pm 5 -percent error in each discharge measurement.

a From city of $\overline{0}$ lean records.

b Estimated. 
The shallow aquifer is also recharged by underflow of ground water in the Allegheny River and 0lean Creek valleys east and north of olean. Calculations based on aquifer transmissivities ranging from 10,000 to $40,000 \mathrm{ft} / \mathrm{d}$ and the hydraulic gradient and cross-section length of flow indicated in plate 2

suggests that underflow in these areas is 0.5 to $2.0 \mathrm{Mgal} / \mathrm{d}\left(0.8\right.$ to $\left.3.1 \mathrm{ft}^{3} / \mathrm{s}\right)$. F1 ow in the 0lean Creek valley would be 0.2 to $0.9 \mathrm{Mgal} / \mathrm{d}(0.3$ to $1.4 \mathrm{ft} / \mathrm{s})$. In the Al legheny River valley, underflow would range from 0.3 to $1.1 \mathrm{Mga} 1 / \mathrm{d}$ $\left(0.5\right.$ to $\left.1.7 \mathrm{ft}^{3} / \mathrm{s}\right)$.

\section{Other Ground-Water Discharges}

Under nonpumping conditions, ground water would flow through the principal sand and gravel aquifer toward the major streams and eventually discharge into the stream channels, through which it drains from the study area. This ground-water discharge sustains the base flow of streams during fair weather. However, as shown in plate 2, pumping near streams has 1 owe red water levels adjacent to streams and thereby reduced the amount of ground water discharging into the streams. At some locations, this reversal of hydraulic gradient near the streams has caused induced infiltration of stream water into the aquifer.

Water levels shown in plate 2 indicate that ground water discharges to some reaches of 0lean Creek and Allegheny River away from major pumping centers. Two-mile Creek is an ephemeral stream and is not a point of discharge. Reaches of Olean Creek where ground-water discharge is likely include those above streamflow-measurement site $6(\mathrm{pl} .4)$ and below site 7 to the Allegheny River. Along the Allegheny River, ground water probably discharges to river reaches just upstream from 0lean Municipal well field (p1. 3) and downstream from the oil company's well field southwest of olean. The ground-water discharges to these streams we re estimated during model calibration because no measurements had been made along these reaches of Olean Creek and Al legheny River to quantify them.

Some ground water is discharged from the shallow aquifer by direct evaporation or transpiration from the water table. However, because depths to water throughout the study area are generally greater than $10 \mathrm{feet}$, except close to streams, the effect of direct evaporation or transpiration on the aquifer is likely to be minimal. The primary effect of evapotransporation on the aquifer system is the reduction of recharge to the saturated zone.

\section{Water-Level Fluctuations}

Water levels in wells completed in the shallow sand and gravel aquifer fluctuate daily and seasonally in response to variations in recharge and discharge. Hydrographs of wells in two different areas (fig. 3) indicate that the annual fluctuation is generally about 10 to $20 \mathrm{ft}$. Water levels are commonly highest during April and May--a period of large surface-water runoff-and lowe st in November and De cember.

We11 7 and we11 14 are both near major well fields (p1.3). However, we11 7 is influenced by stage of the Allegheny River becaust it is near the river. An example of this response during the summer of 1972 is apparent in figure 3. In June of that year, rainfall and resultant run of $f$ associated with 


\section{DISTRIBUTION OF NITROGEN COMPOUNDS IN THE AQUIFER SYSTEM}

Water samples from the production wells in the oil company's well field at the industrial park have been analyzed for ammonia and nitrate on a regular basis since 1969. During this period, samples from many observation we 11s have been also analyzed by the oil company and fertilizer company. A $f$ ew samples were analyzed by other laboratories, including the New York State Department of Health.

In general, ground water has contained less than $0.3 \mathrm{mg} / \mathrm{L}$ ammonia and 4 to $10 \mathrm{mg} / \mathrm{L}$ nitrate east of the complex, and less than $1 \mathrm{mg} / \mathrm{L}$ ammonia and 1 to $4 \mathrm{mg} / \mathrm{L}$ nitrate west of the complex (Randa11, 1976). Within the complex, highest concentrations of ammonia and nitrate have been found in observation wells about $2,000 \mathrm{ft}$ southwest of the center of the well field. During 1970-74, concentrations of ammonia plus nitrate regularly exceeded $2,000 \mathrm{mg} / \mathrm{L}$ as nitrogen in three we $11 \mathrm{~s}$ and reached $7,200 \mathrm{mg} / \mathrm{L}$ in another well.

As a result of continuous pumping from the oil company's we 11 field and the fertilizer company's purge we11, nitrogen concentrations in the aquifer have declined substantially during the 1970's. In 1979, however, nitrogen concentrations in some wells still ranged from 100 to $1,840 \mathrm{mg} / \mathrm{L}$. In several other wells, concentrations have remained unchanged (Hydro Systems, Inc., 1980).

A geologic section ( $\mathrm{Al}-\mathrm{A} 1^{\prime}$ ) through the Olean Nitrogen Complex (fig. 4) and a map of the complex (figs. 5A, 5B) illustrate the vertical and areal distribution of nitrogen concentrations in the upper and lower parts of the aquifer. These data indicate that nitrogen concentrations are higher in water from wells completed in the upper part of the aquifer than in wells tapping the lower part. Nitrogen concentration in the upper part generally ranges from background levels of about $1 \mathrm{mg} / \mathrm{L}$ in domestic wells near the complex to as high as $1,840 \mathrm{mg} / \mathrm{L}$ in observation well $3 \mathrm{~S}$ ( $\mathrm{fig}$. 5A). Nitrogen concentration in water from the deeper part of the aquifer generally ranges from background levels of less than $2 \mathrm{mg} / \mathrm{L}$ outside the nitrogen complex to $45 \mathrm{mg} / \mathrm{L} \mathrm{near}$ the fertilizer company's purge well.

Additional information on the nature and distribution of nitrogen compounds in the aquifer is given in reports by Hydro Systems (1975-1980) and by Randal1 (1977-78).

\section{DIGITAL MODEL ANALYSIS OF THE AQUIFER SYSTEM}

Digital-modeling techniques were used to simulate ground-water flow in the shallow sand and gravel aquifer. The mode 1 was used to estimate the hydrologic effects of a partial or a full shutdown of the oil company's well fields and the relocation of the discharge of the fertilizers company's proc ess water from Twomile Creek to Allegheny River. The resulting changes in ground-water levels, ground-water flow patterns, and streamflow we re then used to evaluate the potential for movement of nitrogen-bearing ground water from the North olean area. 
Hurricane Agnes caused water levels in well 7 to rise 10 to $15 \mathrm{ft}$ above normal (well 7, fig. 3).

Observation we 1114 is near the oil company's well field and far from the Allegheny River and 0lean Creek. Because of its location, significant variations in local pumping have caused water levels in the we 11 to deviate from the normal patterns of fluctuation. For example, a 3-month shutdown of the North 0lean well field during November 1979 to February 1980 caused water levels in the well to rise and peak 2 to 3 months before the normal time, as shown in the hydrograph for well 14 ( $f$ ig. 3 ).

The hydrographs in figure 3 indicate that, although water levels fluctuate seasonally, they return to normal during late winter and early spring. Annual deviations from mean April water levels in wells 7 and 14 during 1972-81 average $2.5 \mathrm{ft}$; these deviations are the result of natural changes in recharge and gradual changes in pumping from year to year. The small magnitude of these changes indicates that the aquifer system is in natural equilibrium.

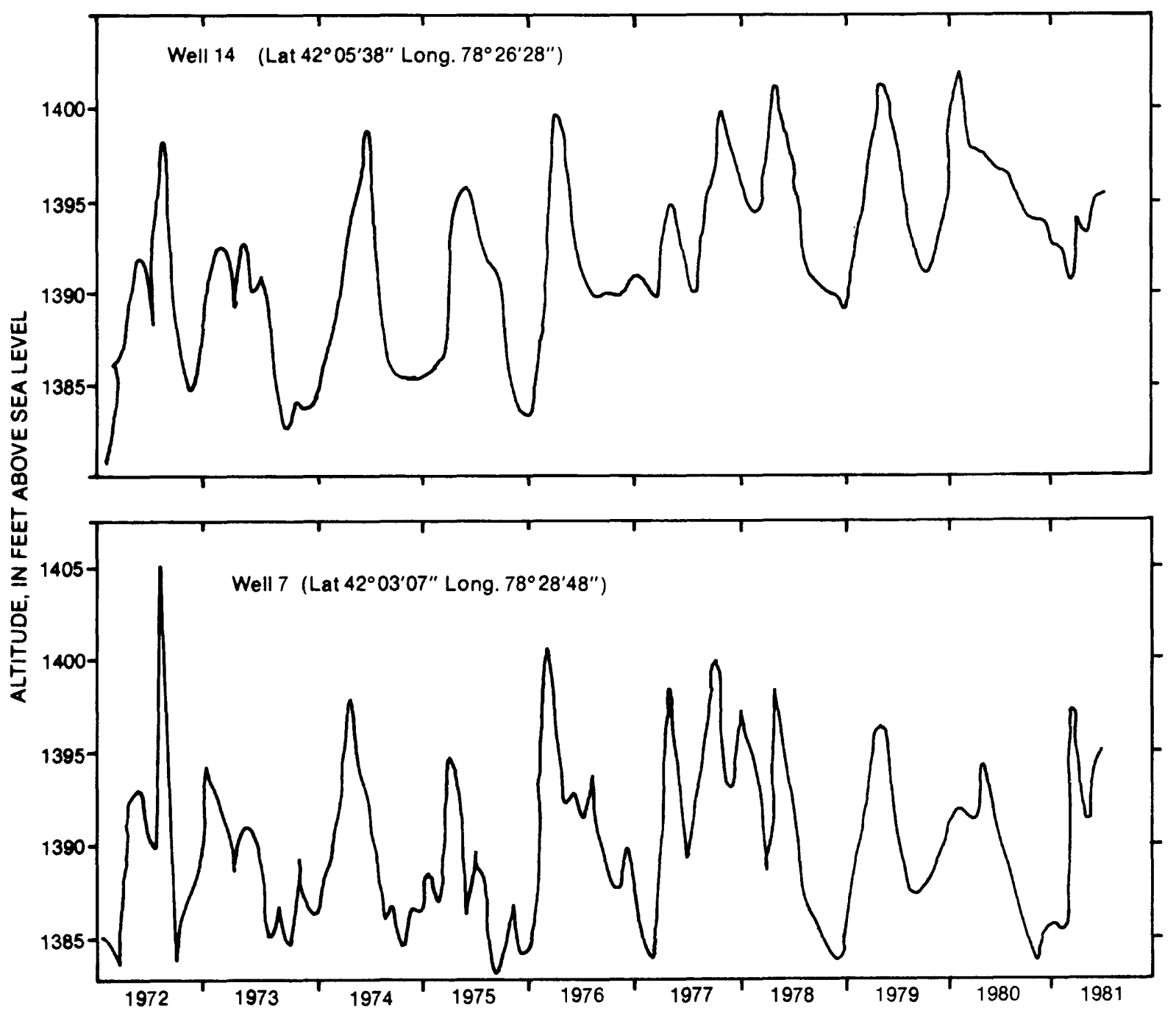

Figure 3.-Water-level fluctuations in wells 7 and 14 during 1972-81. 

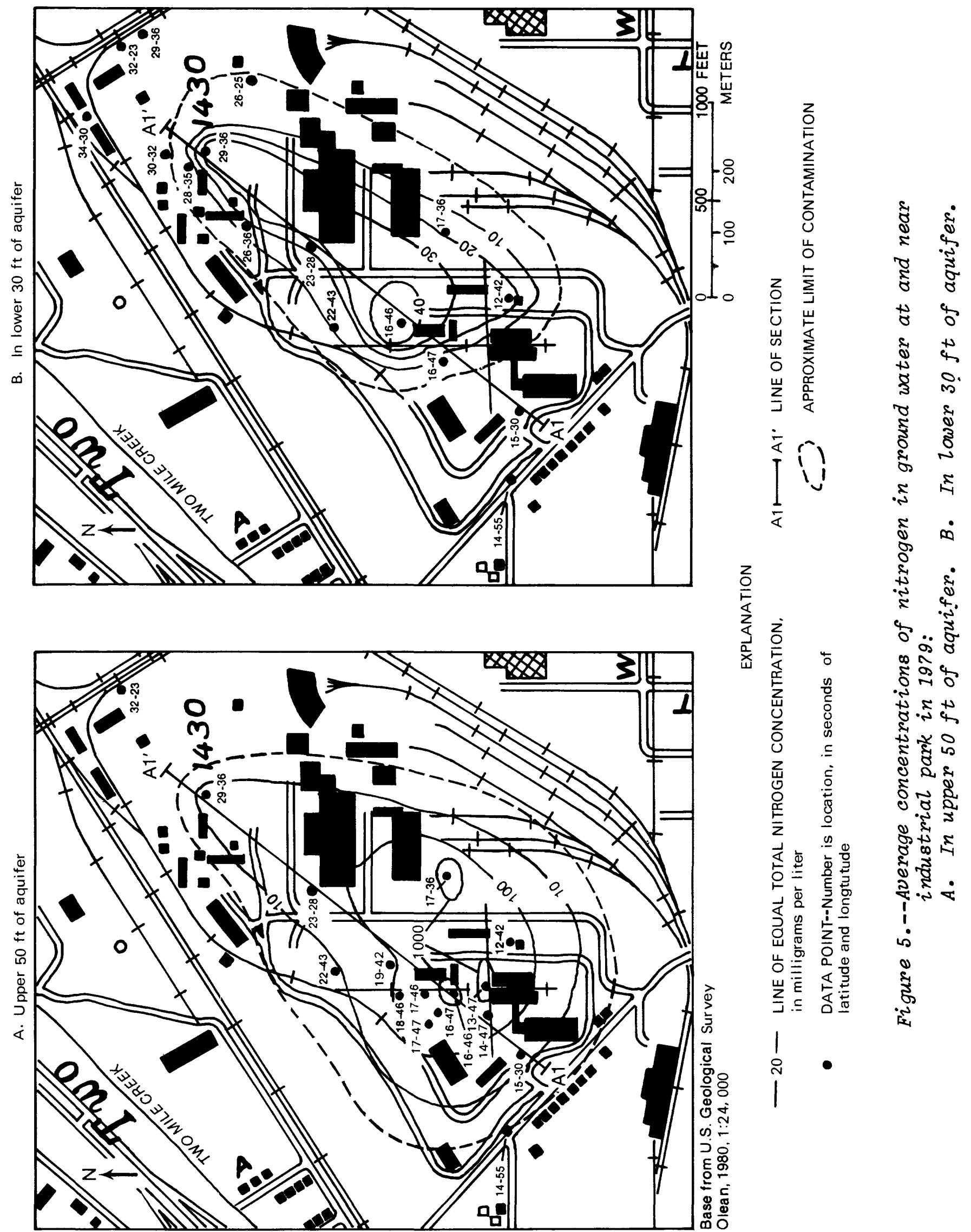


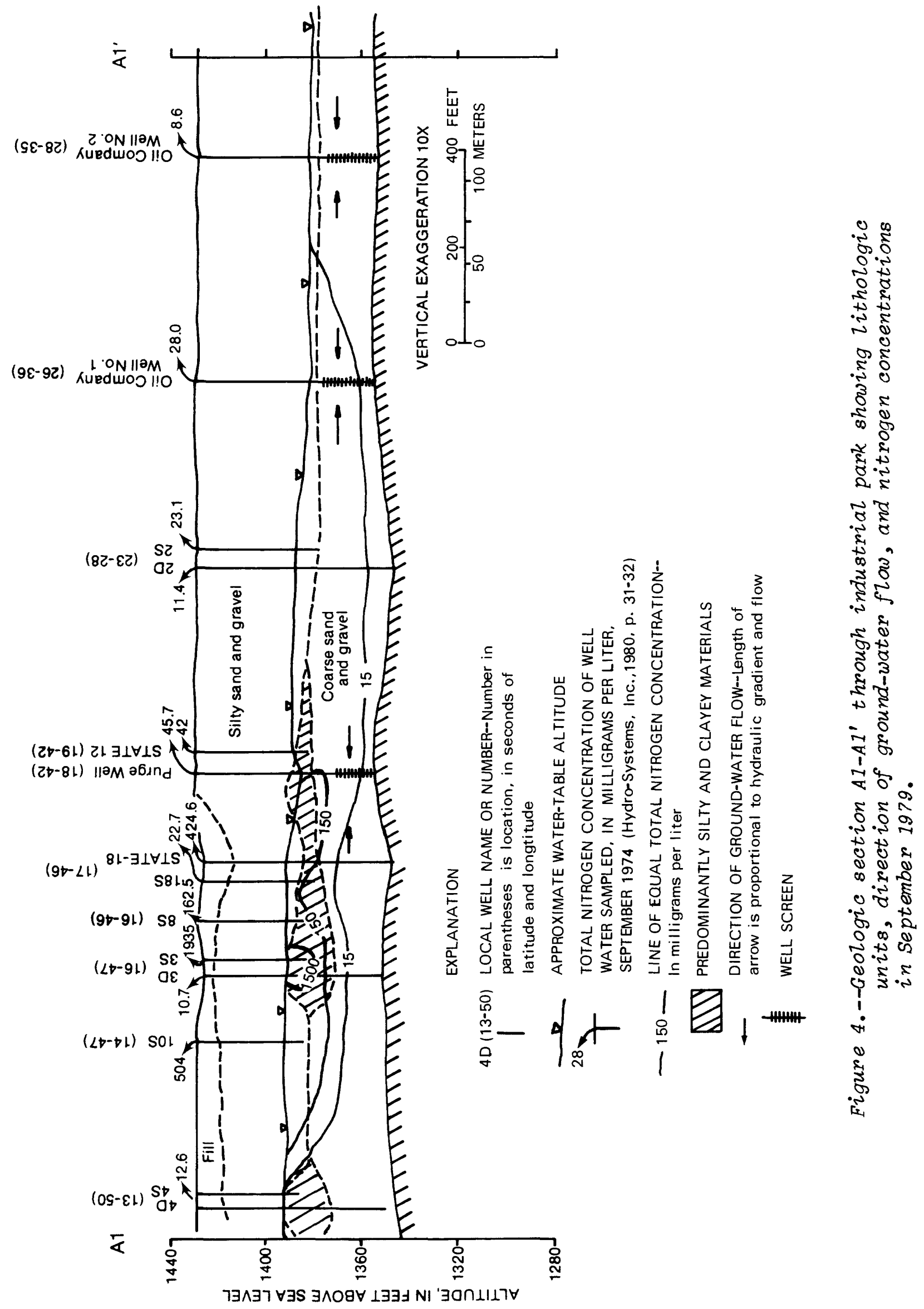


single sand and gravel unit with no vertical variation in hydraulic conductivity, as depicted beneath the Allegheny River, the upper half of the unit was considered the upper aquifer (layer 1), and the lower half was considered the lowe $r$ aquifer (layer 2). In some areas of the model, the sand and gravel was sufficiently thin that its entire thickness was considered the upper aquifer; the lower aquifer was then assigned a low transmissivity and ignored in the simulation. In some areas, upper parts of the aquifer system are significantly less permeable than lower parts, as shown near the pumping well. In this case, the upper, less permeable part was assigned to the upper aquifer (1 ayer 1), and the lower, more permeable part was assigned to the lower aquifer (layer 2).

Use of two aqui fer layers connected by a vertical-conductance term represented the aquifer system adequately. The lower layer (layer 2) represents the deeper (confined) aquifer; the upper layer (1ayer 1) represents the surficial (unconfined) aquifer. For the deeper aquifer, a confined version of equation 2 is used in the model. Hydraulic conductivity variables $k_{x x}$ and $\mathrm{K}_{\mathrm{yy}}$ are changed to $\mathrm{T}_{\mathrm{xx}} / \mathrm{b}$ and $\mathrm{T}_{\mathrm{yy}} / \mathrm{b}$, where $\mathrm{K}_{\mathrm{xx}}$ and $\mathrm{K}_{\mathrm{y}}$ are the principal components of transmissivity, and $b$ is the saturated thickness of the aquifer. Transmissivity and ( $o r$ ) hydraulic conductivity of the upper, lower, or combined aquifers was estimated from specific-capacity data, results of drillers' pumping test of production wells, or simple two-dimensional digital models of well fields.

SOUTHWEST NORTHEAST

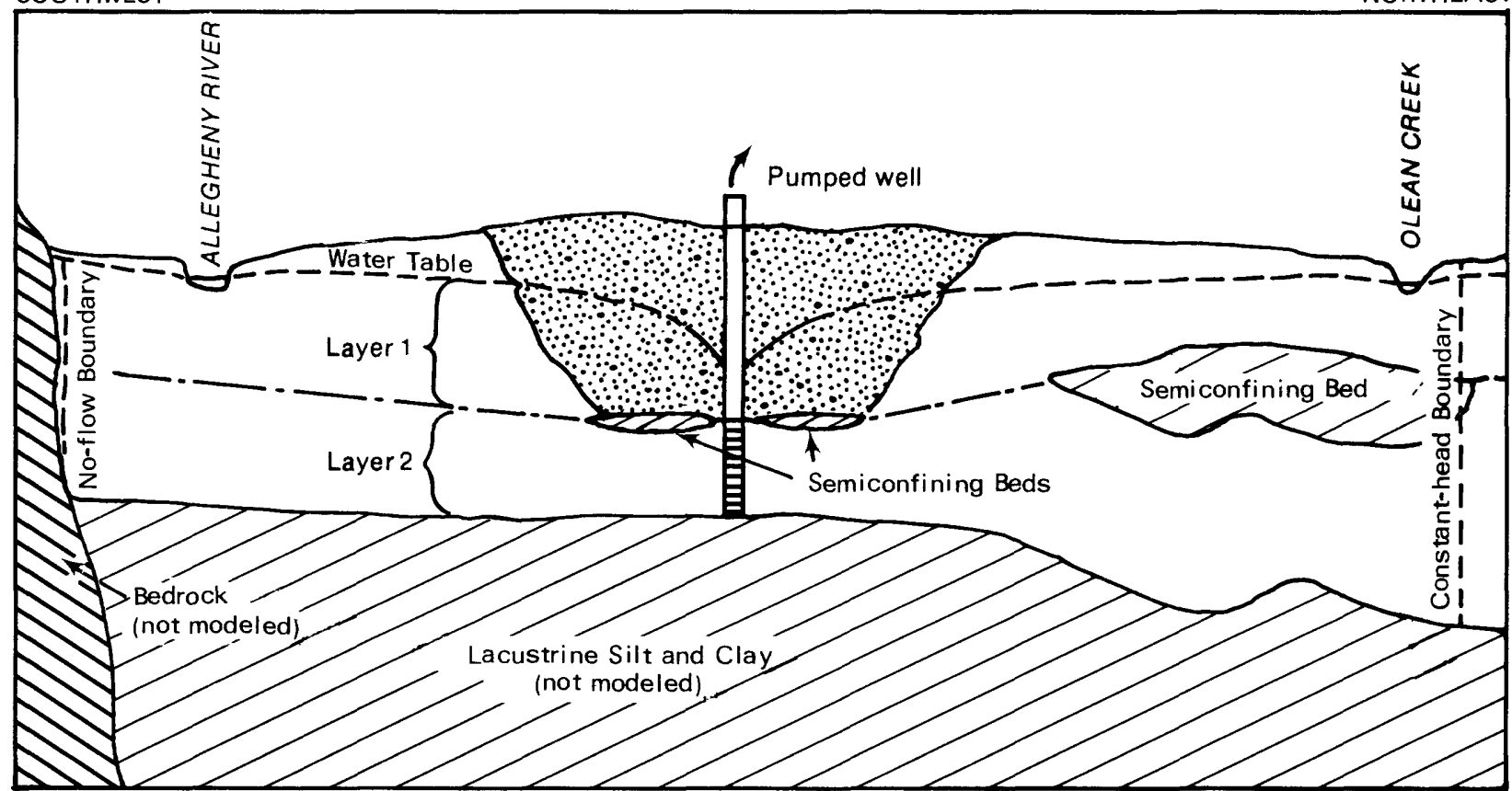

SAND AND GRAVEL

SILTY SAND AND GRAVEL

D TILl and/OR LaCustrine SILt AND Clay
EXPLANATION

SHALE BEDROCK
- GEOLOGIC CONTACT

- MODEL LAYER CONTACT

Figure 6.--Generalized geologic section showing aquifer layering used in digital model. 


\section{Model Selection and Design}

A three-dimensional model developed by McDonald and Harbaugh (1983) was. selected to simulate flow within the aquifer system. Finite-difference techniques are used in the model to solve the following partial differential equation:

$$
\frac{\partial}{\partial x} K_{x x} \frac{\partial h}{\partial x}+\frac{\partial}{\partial y} K_{y y} \frac{\partial h}{\partial y}+\frac{\partial}{\partial z} K_{z z} \frac{\partial h}{\partial z}=S_{s} \frac{\partial h}{\partial t}+W(x, y, z, t)
$$

where: $\mathrm{K}_{\mathrm{xx}}, \mathrm{K}_{\mathrm{yy}}$, and $\mathrm{K}_{\mathrm{z} z}$ are the principal components of hydraulic conductivity tensor ( $\mathrm{L} / \mathrm{T})$;

$$
\begin{aligned}
& \mathrm{h}= \text { the potentionetric head }(\mathrm{L}) ; \\
& \mathrm{t}= \mathrm{t} \text { ime }(\mathrm{T}) ; \\
& \mathrm{S}= \text { the specific storage of the aquifer }\left(\mathrm{L}^{-1}\right) ; \\
& \mathrm{L}, \mathrm{y} \text { and } \mathrm{z} \text { Cartesian coordinates }(\mathrm{L}) ; \\
& \mathrm{W}= \text { the volumetric flux per unit volume }\left(\mathrm{L}^{3} / \mathrm{T} / \mathrm{L}^{3}\right) \text { and } \\
& \text { represents sources and (or) sinks of water; and } \\
&+ \text { or }- \text { water is added to }(+) \text { or withdrawn from }(-) \\
& \text { the system. }
\end{aligned}
$$

The model version used in this analysis is quasi-three-dimensional because it simulates flow in a multiaquifer system by assuming horizontal flow in the aquifers and vertical flow in semiconfining beds.

The digital model is based on a rectangular, blpck-centered, finitedifference grid (p1. 5) representing $24.3 \mathrm{mi}^{2}$ ( 4.5 by $5.4 \mathrm{mi}$ ). The grid contains 5,494 (67 by 81 ) grid spaces, or nodes. (A node is defined as the center of each grid space.) Variable grid spacing was selected so that locations of major pumping wells, rivers, and streams could be simulated in finer detail. Grid spaces range in size from $20,720 \mathrm{ft}^{2}(185 \mathrm{ft}$ by $112 \mathrm{ft}$ ) to $1,300,000 \mathrm{ft}^{2}(1,300 \mathrm{ft}$ by $1,000 \mathrm{ft})$.

\section{Conceptual Model}

\section{Model Layering}

The shallow aquifer system at olean can be thought of as a single heterogeneous aquifer that varies in saturated thickness and in lateral and vertical hydraulic conductivity. In some localities, the aquifer contains fairly continuous confining beds that restrict flow between upper and lowe $r$ parts. If the system we re considered a single aquifer for sinulation of ground-water flow, however, the effects of vertical variations in hydraulic conductivity and confining beds could not be incorporated into the simulation. Consequently, for simulation purposes, the aquifer system was divided into two layers.

A schematic hydrogeologic section through the aquifer system shown in figure 6 il lustrates the layering used to represent the system at any locality. Where the aquifer contains confining beds such as shown beneath olean Creek, saturated sand and gravel above the confining beds was considered the upper aquifer ( 1 aye $\mathrm{r} 1$ ), and sand and gravel below the confining beds was considered the lowe $r$ aquifer (layer 2). In areas where the aquifer contains a 
where: $\mathrm{K}_{\mathrm{v}}$ = vertical hydraulic conductivity of the streambed ( $\left.\mathrm{L} / \mathrm{T}\right)$,

$\mathrm{m}=$ streambed thickness (L),

$A_{S}=$ area of the stream $\left(\mathrm{L}^{2}\right)$,

$L=$ unit length ( $L)$, and

$T$ = unit time.

The vertical hydraulic conductivity $\left(\mathrm{K}_{\mathrm{v}}\right)$ of all streambeds was first assumed to be $1.0 \mathrm{ft} / \mathrm{d}$. This value implies some fine-grained material and a low vertical hydraulic conductivity. The $\mathrm{K}_{\mathrm{v}} / \mathrm{m}$ term may be a function of the vertical permeability, anisotropy of the underlying shall ow aquifer, or a reflection of the hydraulic properties of a thin silty alluvium overlying the aquifer. The streambed thickness of all streams was assumed to be $1 \mathrm{ft}$, and the area of each stream was estimated from the approximate stream width multiplied by the length of stream in each stream node.

St age at each stream node was assigned by adding a representative lowflow depth of water to stream-bottom altitudes estimated from topographic maps. Depth of water in Allegheny River and 01 ean Creek was estimated to be 2 $\mathrm{ft}$ and $1 \mathrm{ft}$, respectively; depth in Twomile Creek below the outfall of the fertilizer company ( $r$ each $C, D$, and $E$ ) was estimated to be $1 \mathrm{ft}$ and from the outfall upstream to the Johnson Street Bridge (reach B) was estimated to be $0.5 \mathrm{ft}$. A depth of $0 \mathrm{ft}$ was assigned to the reach above the Johnson Street Bridge, which is normally dry during low-flow periods.

\section{Boundary Conditions}

Boundary conditions in the model were defined to have minimal effect on the results of simulated stresses. Flow in the two-1ayer aquifer system was bounded at the valley walls by impermeable or no-flow boundaries to coincide with the impermeable shale walls of the real system. In East Olean, the kame terraces in area 10 were excluded from the simulation because they do not appear to be hydraulically connected nor are they likely to contribute a significant amount of water to the principal confined aquifer in the center of the valley. Although these areas probably provide minor recharge to the real ground-water system, the volume can be considered negligible for modeling purposes. Locations of no-flow boundaries are shown in plate 5 .

The three valley entrances into the model area were treated as constanthead boundaries except for an area along the west boundary, which was simulated as a no-flow boundary because its water-level contours (pl. 2) meet the western boundary of the model at nearly right angles, which indicates little or no flow across this boundary. These boundaries were selected to represent underflow of ground water into and out of the model area. Values for each constant-head-boundary node were selected from potentiometric-surface maps of the aquifer.

The last boundary condition to be considered in the model was the hydraulic relationship between the sand and gravel outwash aquifer and the underlying lacustrine clay and silt. Because these underlying units are practically impermeable and probably contribute little to the total water budget of the outwash aquifer system, they were represented as an impermeable base and were not considered in the model analysis. 
In the mode1, the previously described geologic areas $2,3,5,6 \mathrm{~A}$, and 8 were simulated as containing an upper and a lower aquifer separated by a semiconfining layer. Areas 1 and 4 were modeled similarly, except that the lowe $r$ aquifer was assigned a low transinissivity and was ignored in calibration because these areas show little evidence of a deeper aquifer. In area 8 , the upper layer represented the surficial, fine-grained materials and the alluvial s and and gravel along the Allegheny River; the lower layer represented the confined sand and gravel aquifer of this area. The thicker surficial aquifers in areas 6 and 7 were generally represented as two aquifers separated by a relatively permeable semiconfining layer. In these areas, the two aquifers function as one with nearly identical heads. Intervening areas not labeled as area 9 in plate 1 were interpreted on the basis of the few available well logs and by extrapolation from the better defined areas. Barriers of 1 ow permeability were initially assumed around margins of areas 1 and 2 because the upper and the lowe $r$ aquifers in these areas may be older than aquifers of similar stratigraphic positions in adjacent areas, and lateral flow in these areas may be restricted by the deposits of low permeability.

\section{Vertical Leakance Between Layers}

Fl ow in the semiconfining beds separating the upper and lower aquifers was simulated with a vertical-leakance term. This term is defined as the effective vertical hydraulic conductivity of the material between two vertical adjacent nodes divided by the thickness of the material between the nodes. For clay or silty clay, vertical hydraulic conductivity of these fine-grained materials was initially estimated to be $1.3 \times 10^{-4} \mathrm{ft} / \mathrm{d}$, which is comparable to values for clay and silty clay determined by Prudic and Randal1 (1979) near West Valley in northeast Cattaraugus County. Vertical leakance was approximated by dividing this estimated hydraulic conductivity by the thickness of the fine-grained material. For areas where no confining layer is present, the vertical hydraulic conductivity of the sand and gravel deposits, which can probably range from $1 / 100$ to $1 / 10$ of the horizontal hydraulic conductivity, was first estimated to be $1 / 30$ of the horizontal hydraulic conductivity. The vertical leakance tem was calculated by dividing this estimate by half of the combined saturated thickness of the aquifer.

\section{Stream Seepage}

The interaction between ground water and surface water within the aquifer system and three streams--Allegheny River, O1 ean Creek, and Twomile Creek--was simulated in 229 nodes ( 1 . 5). These streams were simulated as headdependent leakage boundaries capable of providing either a source of induced infiltration or a discharge point for ground water. Al1 stream nodes were simulated as being hydraulically connected to the upper aquifer (1ayer 1 ). The model calculates leakage at each stream node by multiplying the streambed conductance by the gradient resulting from thr difference between an assigned stream stage and a computed water level in the upper layer of the model. The streambed conductance, $C_{R}$, is defined by the following equation.

$$
C_{R}=\frac{K_{\mathbf{v}}}{\mathrm{in}} \times A_{S}
$$




\section{Steady-State Calibration}

Before a model can be used to simulate the effect of hypothetical conditions on ground-water levels, ground-water flow patterns, and streamflow, it must be capable of simulating observed conditions in the aquifer system to an acceptable degree. For purposes of this study, the olean model was calibrated to average water levels measured in spring and fall 1981 and to ground-water discharges calculated from the base-flow measurements made on Twomile Creek and 0lean Creek in 1977 and 1978. Calibration was done to steady state to represent average 1981 conditions because this period represented the most current conditions in 01 ean and because pumpage during this time was fairly constant. In recent years, pumpage in olean has undergone significant changes such as a 3-month shutdown of the oil company's well in 1979 and the shutdown of the City of 0lean well field in early 1981. Because many instances of pumping changes occurred over only a part of any given year, steady-state calibration to other periods would have been difficult.

\section{Parameter Adjustment}

The calibration procedure consisted of varying hydrologic values in the model until simulated water-levels and discharge to or from streams matched field measurements. The aquifer transmissivities and constant-head boundaries were estimated from field data and, thus, were fairly well defined. The effective recharge rate and the vertical leakance and streambed conductance simulating flow between the upper and lower aquifers, however, are not based on field data and consequently are less certain. Therefore, calibration centered largely on these terms.

Several recharge rates, ranging from 13.5 to $30 \mathrm{in} / \mathrm{yr}$ were used in model calibration to represent the effective areal recharge to the ground-water system. A value of about $19 \mathrm{in} / \mathrm{yr}$ yielded the best match between simulated water levels and average water levels observed in 1981, except in an area in East 0lean (area 8) where 30 to $60 \mathrm{ft}$ of fine-grained till and flood-plain sediments of low permeability are at the surface. No water-level information from shallow depths in East 0lean was available. Recharge rates were adjusted until reasonable water levels ( 5 to 10 feet below land surface) we re estab1ished. The recharge rate that provided an acceptable level of saturation for this area was $1.8 \mathrm{in} / \mathrm{yr}$.

Vertical hydraulic-conductivity values used to simulate vertical leakage between aquifer layers was first estimated to be $1.5 \times 10^{-9} \mathrm{ft} / \mathrm{s}$ in areas where clay or fine-grained materials are present and was assumed to be $1 / 30$ of the estimated horizontal conductivity of the outwash sand and gravel where fine-grained materials are absent. Only minor adjustments to these initial values were needed to obtain an acceptable match between simulated head distributions and observed data. In areas containing significant confining beds, final values of vertical hydraulic conductivity of the confining layer ranged from $1.2 \times 10^{-5}$ to $1.3 \times 10^{-3} \mathrm{ft} / \mathrm{d}$. Vertical leakance values ranged from $8.6 \mathrm{x}$ $10^{-7}$ to $8.6 \times 10^{-5}$ per day. In areas where fine-grained materials are absent, final values of vertical hydraulic conductivity ranged from 0.35 to $2.1 \mathrm{ft} / \mathrm{d}$; vertical leakance values ranged from $8.6 \times 10^{-3}$ to $5 \times 10^{-2}$ per day. 
In the first estimate of the streambed conductance, a streambed thickness of $1 \mathrm{ft}$ and a streambed vertical hydraulic conductivity of $1 \mathrm{ft} / \mathrm{d}$ were assumed. Adjustments made during calibration resulted in final values that $r$ anged from 0.001 to $6.2 \mathrm{ft} / \mathrm{d}$, with most between 0.1 and $2.0 \mathrm{ft} / \mathrm{d}$. Deviations outside this range are probably the result of an inaccurate estimate of streambed thickness and, to a lesser extent, of streambed area. Streambed conductances resulting from these hydraulic conductivities ranged from 2.0 to $1.0 \times 10^{5} \mathrm{ft}^{2} / \mathrm{d}$. The large range in conductance is partly attributable to differences in streambed permeabilities. The range also reflects the variation in streambed areas, which range from as little as $1,500 \mathrm{ft}^{2}$ on Twomile Creek to as much as $120,000 \mathrm{ft}^{2}$ on the Allegheny River. Ranges of vertical hydraulic conductivity of streambeds and conductances for various stream reaches are summarized in table 2.

Table 2.--Range of final vertical hydraulic conductivity for streambed and conduct ance values for modeled stream reaches.

\begin{tabular}{|c|c|c|c|c|c|}
\hline \multirow[b]{2}{*}{ Stream name } & \multirow{2}{*}{$\begin{array}{l}\text { Stream } \\
\text { reach }\end{array}$} & \multicolumn{2}{|c|}{$\begin{array}{l}\text { Streambed vertical hydraulic } \\
\text { conductivity (ft/d) }\end{array}$} & \multicolumn{2}{|c|}{$\begin{array}{l}\text { St re am bed conductance } \\
\left(\mathrm{ft}^{2} / \mathrm{d} \times 10^{2}\right)\end{array}$} \\
\hline & & Min. & Max. & Min. & Max. \\
\hline Twomile Creek & A & 0.001 & 0.01 & 0.02 & 0.16 \\
\hline Do. & B & .001 & .01 & .02 & .16 \\
\hline Do. & C & .025 & 1.5 & 3.85 & 22.46 \\
\hline Do. & D & .80 & 3.8 & 12.10 & 57.89 \\
\hline Do. & $\mathrm{E}$ & 1.44 & 5.4 & 21.60 & 81.22 \\
\hline 01 ean Creek & F & .8 & 3.1 & 233.28 & 345.60 \\
\hline Do. & G & .5 & 6.2 & 86.4 & 622.08 \\
\hline Do. & $\mathrm{H}$ & 1.0 & 4.7 & 112.32 & 699.84 \\
\hline Al legheny River & $\mathrm{J}$ & .23 & 1.5 & 138.24 & 466.56 \\
\hline Do. & K & .22 & 1.2 & 43.2 & 216.00 \\
\hline Do. & $\mathrm{L}$ & .22 & 2.0 & 86.4 & 1028.16 \\
\hline
\end{tabular}

1 Stream reaches are delineated on plate 4.

Changes in the transmissivity values within layers 1 and 2 during calibration were minor. Transmissivity values resulting from calibration, shown in plates 6 and 7 , were still within the range of values calculated from pumping tests and specific-capacity data. The combined transmissivity of model layers 1 and 2 generally $\mathrm{r}$ anged from less than $1,000 \mathrm{ft}^{2} / \mathrm{d}$ in areas where the aquifer is thin along the valley walls to as much as $100,000 \mathrm{ft}^{2} / \mathrm{d}$ in the thickest and most permeable parts of the aquifer. Simulated transmissivities commonly $r$ anged from 20,000 to $40,000 \mathrm{ft}^{2} / \mathrm{d}$.

\section{Results}

The deviations between average measured 1981 water levels and simulated water levels in nodes that approximated the location of 68 wells are shown on plates 8 and 9 and given in table 3. These data indicate a favorable match 


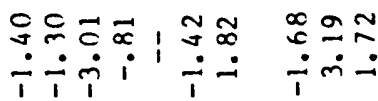

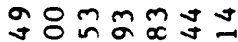

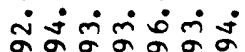

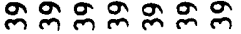

- - - - -

NNNNNN

กิำำก xที่ทีค-

$\stackrel{\infty}{2}$

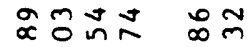

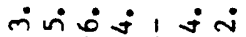

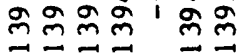

in 0 足 i் हิ

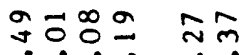

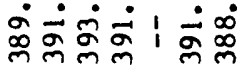

กิธ

iั లి

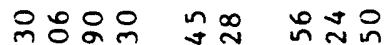

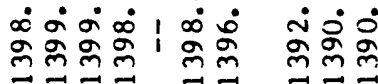

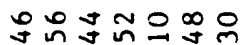
누뉸요 $x \infty \infty \infty \infty \infty$

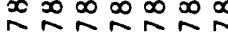

$\neg ン$ $\stackrel{\infty}{\sim} \stackrel{\infty}{\sim}$ $\stackrel{\infty}{\sim} \stackrel{\infty}{\sim}$

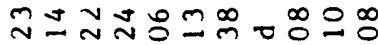

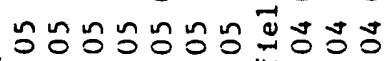

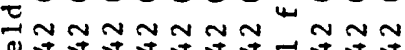

ㅇํำ $\dot{0} \dot{0} \dot{0}$

कें

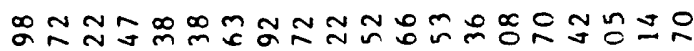
$\dot{i} \dot{i}_{i} \dot{i} i \dot{i} \dot{i} \dot{i} \hat{i} i \dot{i} i \dot{i}$

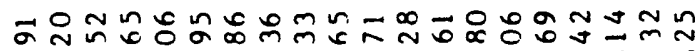

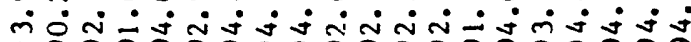

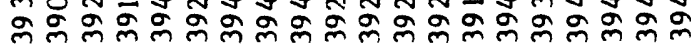

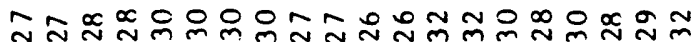

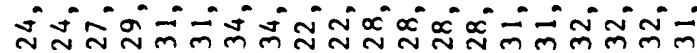

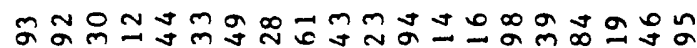

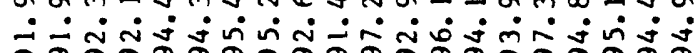

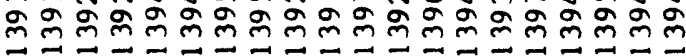

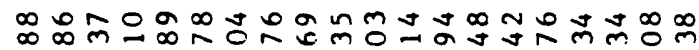

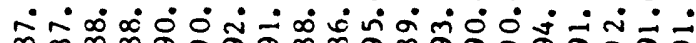

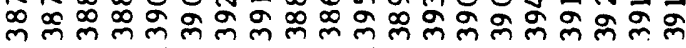

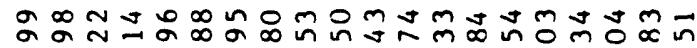

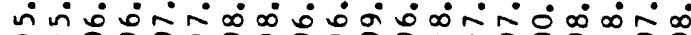

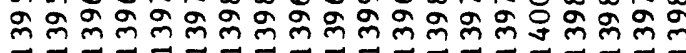

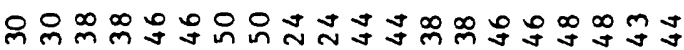

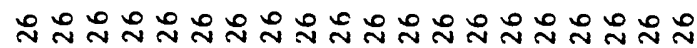

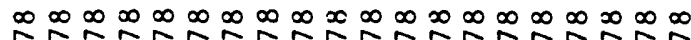

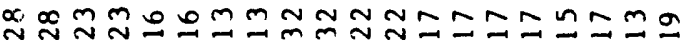

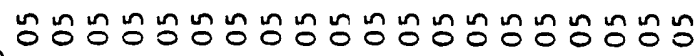

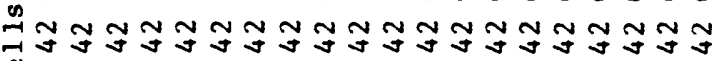
$\vec{\xi}$

胥

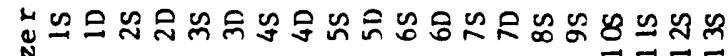




\begin{tabular}{|c|c|c|c|c|c|c|}
\hline 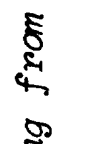 & 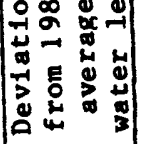 & 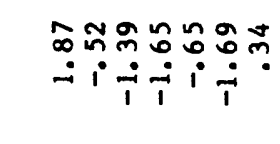 & 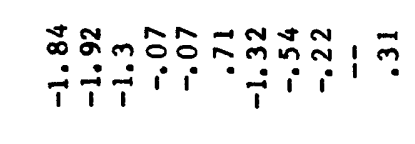 & $\tilde{n}^{n} \mid 1$ & 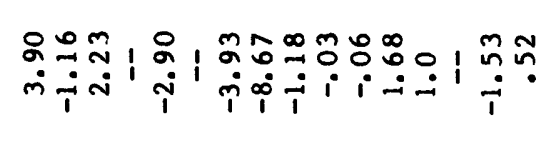 & ตัำ. \\
\hline 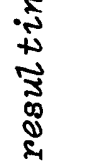 & 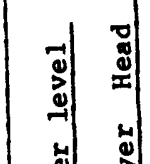 & 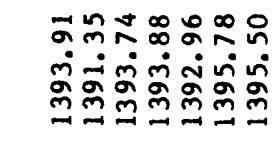 & 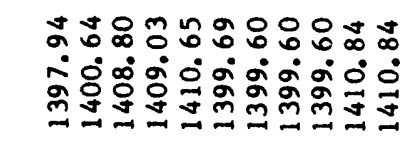 & 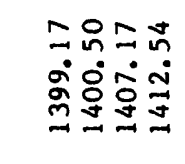 & 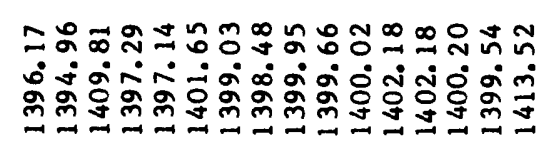 & 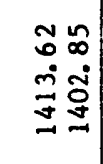 \\
\hline$\frac{9}{\tilde{D}}$ & 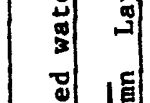 & NNNNNTN & NーNNNーMーーN & nNNN & NNANNN-MNNMTNNN & \\
\hline 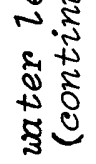 & 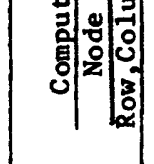 & 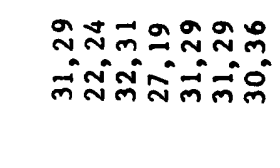 & 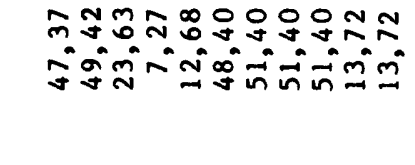 & 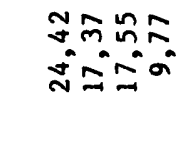 & 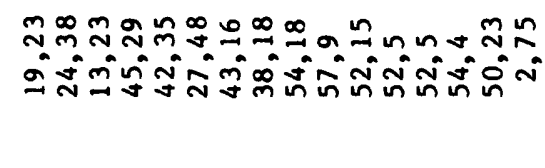 & \\
\hline 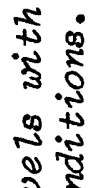 & 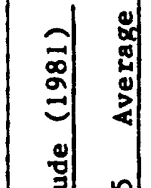 & 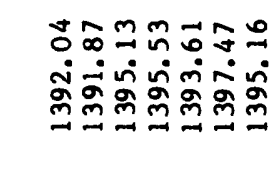 & 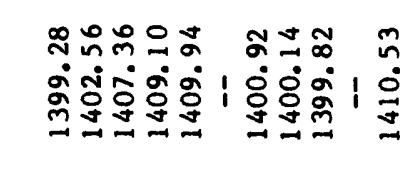 & 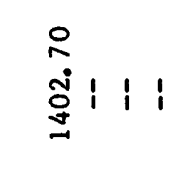 & 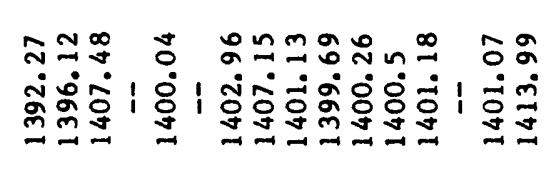 & $\begin{array}{ll}n & 0 \\
\sim & 0 \\
\dot{*} & \dot{0} \\
\pm & \end{array}$ \\
\hline 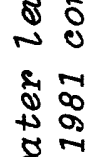 & 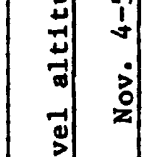 & 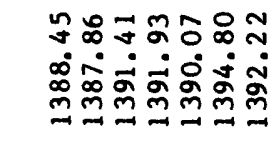 & 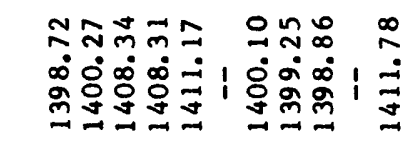 & 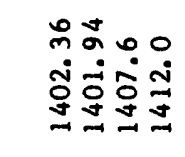 & 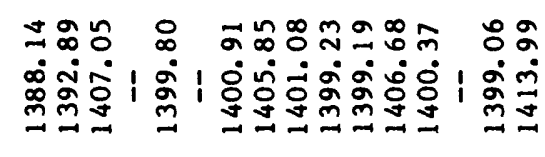 & 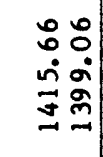 \\
\hline 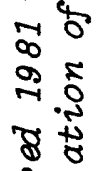 & 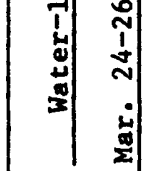 & 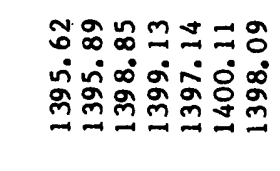 & 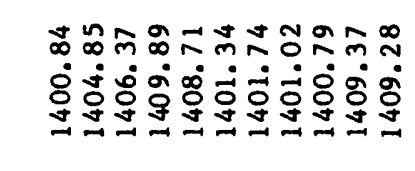 & 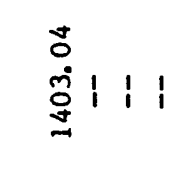 & 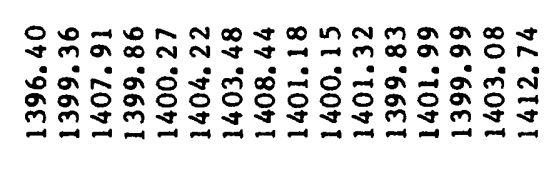 & 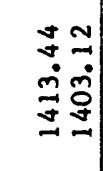 \\
\hline 8. & & 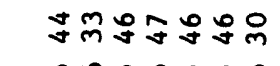 & 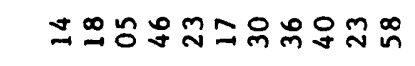 & 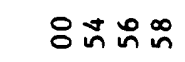 & 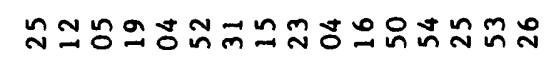 & $\pi \tilde{N}$ \\
\hline$\stackrel{\mathscr{E}}{4}$ & 気- & 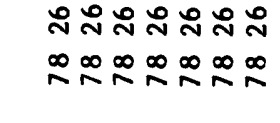 & 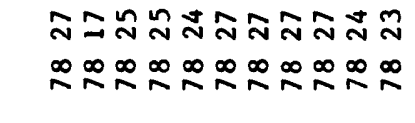 & 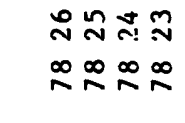 & 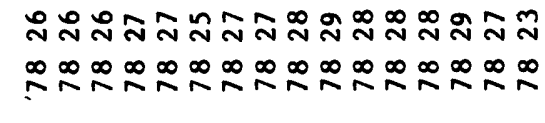 & $\begin{array}{ll}n & n \\
\infty & \infty \\
\sim & \infty\end{array}$ \\
\hline 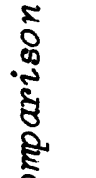 & ": & 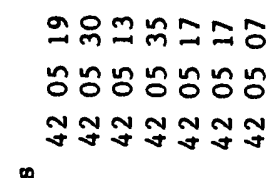 & 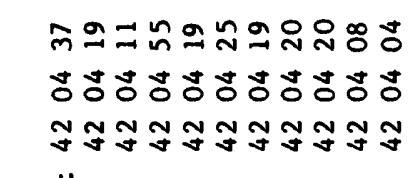 & 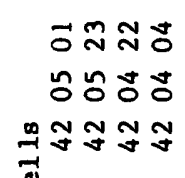 & 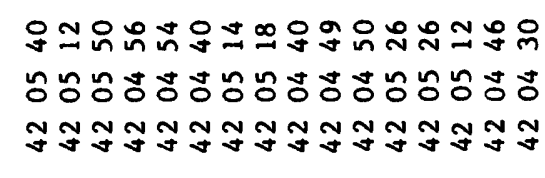 & 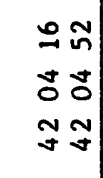 \\
\hline 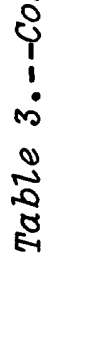 & 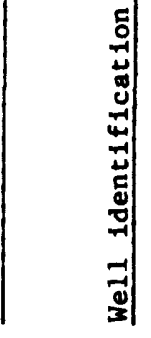 & 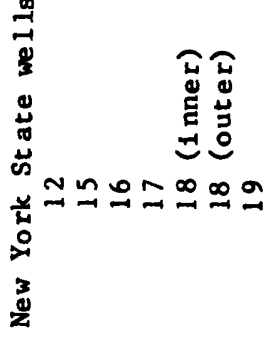 & 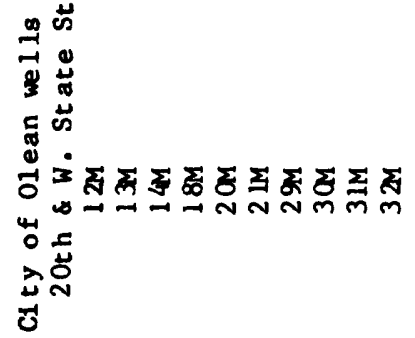 & 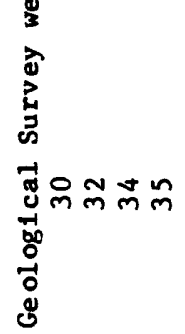 & 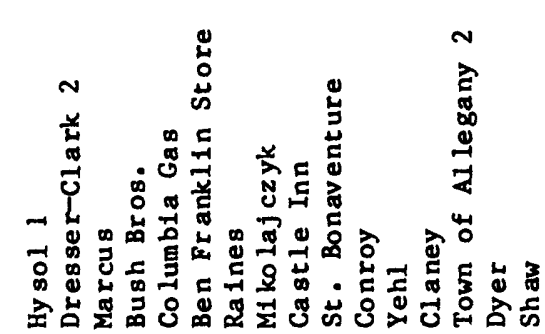 & 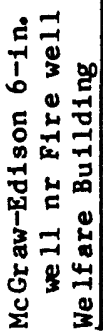 \\
\hline
\end{tabular}


between simulated and observed conditions. Most of the simulated heads were within $3 \mathrm{ft}$, and all but one, at a well in a perched area, were within $5 \mathrm{ft}$ of average measured values. The average deviation of simulated wate $r$ levels from measured levels was $-0.7 \mathrm{ft}$.

In general, the pattern of ground-water flow depicted in the potentiometric-surface map of the aquifer shown in plate 2 is fairly well duplicated in the model-generated water-level distributions in plates 8 and 9. tively large and deep cones of depression are apparent at the oil company's we 11 fields in North 01 ean and along the Al legheny River in both mode 1 laye 1 (p1. 8) and 2 (p1.9). Because model layer 1 represents flow in shallow parts of the aquifer system, some localized perched water-table conditions caused by confining beds are found $(\mathrm{p} 1.8)$ in an area west of the North 0lean well field and on northern and southern sides of the Allegheny River in East Olean.

Mode1-simulated and estimated seepage rates for the three streams are given in table 4. In general, the simulated rates are within 5 percent of the estimated rates. Because no estimates of seepage had been made for either the Al legheny River or parts of Twomile Creek and Olean Creek, the final seepage rates were obtained by adjusting the corresponding streambed conductance until the surrounding distribution of water levels was adequately matched. Consequently, the reliability of simulated seepage rates is unknown, but they provide an indication of locations of gaining and losing reaches.

Table 4.--Estimated and calibrated, steady-state seepage rates for modeled stream reaches.

[Reach locations are shown in pl. 4.]

\begin{tabular}{|c|c|c|c|c|c|}
\hline \multirow[b]{2}{*}{ Stream name } & \multirow[b]{2}{*}{ Reach } & \multicolumn{3}{|c|}{ Estimated rate 1} & \multirow{2}{*}{$\begin{array}{r}\text { Final steady- } \\
\text { state rate }\end{array}$} \\
\hline & & Min. & Actual & Max. & \\
\hline Twomile Creek & A & - & - & -- & 0.0 \\
\hline Do. & B & -0.04 & -0.06 & -0.08 & .04 \\
\hline Do. & C & .88 & .33 & .16 & .31 \\
\hline Do. & D & 1.69 & .35 & -.08 & .35 \\
\hline Do. & $\mathrm{E}$ & - & - & - & .31 \\
\hline Olean Creek & F & 3.24 & .94 & -1.37 & .59 \\
\hline Do. & G & 1.58 & .27 & -2.24 & .97 \\
\hline Do. & $\mathrm{H}$ & -- & -- & -- & -.53 \\
\hline Allegheny River & I & -- & -- & -- & -.98 \\
\hline Do. & $\mathrm{J}$ & -- & - & -- & .88 \\
\hline Do. & $\mathrm{K}$ & -- & -- & -- & 10.14 \\
\hline
\end{tabular}

1 Negative number indicates ground-water discharge to the stream. Dashes indicate no value was estimated. Actual estimated rates of seepage are based on discharge measurements presented in tables $1 \mathrm{~A}$ and $1 \mathrm{~B}$. Minimum and maximum values represent seepage reflecting a \pm 5 -percent error in each discharge measurement. 
The model-generated inflows and discharges of ground water as simulated for the period of calibration are summarized in table 5. The data indicate that 42 percent of ground-water recharge is from precipitation, about 6 percent is from ground-water infl ow at upvalley constant-head boundaries, and 52 percent is from leakage or induced infiltration from streams. Of the discharges, 88 percent is pumpage, 1 percent is outflow at downvalley constant head boundaries, and 11 percent is discharge to streams.

Table 5.--Water budget of the calibrated steady-state model simulating average hydrologic conditions of March-November 1981.

\begin{tabular}{lc} 
Source & $\begin{array}{c}\text { Rate Percentage } \\
\left(\mathrm{ft}^{3} / \mathrm{s}\right) \text { of rate }\end{array}$ \\
\hline
\end{tabular}

Inflows to aquifer

Areal effective recharge from precipitation

\begin{tabular}{rrr} 
& 11.61 & 41.9 \\
& 1.74 & 6.2 \\
& 14.38 & 51.9 \\
Total & & \\
\hline & &
\end{tabular}

Discharges from aquifer

Pumpage

Constant-head boundaries

24.46

88.0

Leakage to streams from

.34

1.2

aquifer through streambeds

$2.98 \quad 10.8$

Total $\overline{27.78} \quad \overline{100.0}$

Percent discrepancy

0.18

\section{EFFECTS OF REDUCTIONS OF INDUSTRIAL PUMPAGE}

The steady-state calibrated model was used to evaluate the hydraulic effects of reduced levels of pumping from some or all production wells at the ol ean industrial park. Model results we re then used to predict the potential for migration of nitrogen-bearing ground water fram the industrial park to nearby private and municipal supply wells.

In all model experiments, constant fluxes derived previously at the constant-head boundaries during model calibration were imposed in place of the constant-head boundary at the same nodes. Because these fluxes remain constant during a simulation, and because no additional water can be induced at the boundaries, constant-flux boundaries tend to maximize water-level and streamflow changes that result from additional simulated stresses.

Constant-head boundaries tend to minimize water-level and streamf $10 \mathrm{w}$ changes because water levels at the boundary are held constant. If little 
difference is noted between the results of a constant-flux and a constant-head boundary simulation, then the boundary condition is not affecting the simulation. Comparison of results from the two boundary types quantifies the minimum and the maximum water-level and streamflow changes that can result from the simulated hydrologic condition. To determine whether constant-flux boundaries were significantly affecting the results of the simulations, additional simulations were made in which constant-head boundaries we re used when water-level changes at any constant-flux boundary exceeded $1 \mathrm{ft}$.

The water-level and streamflow changes discussed in this section reflect only the effect of the simulated stresses and do not account for other stresses within or near the modeled area. Increased or reduced pumping outside the modeled area may alter water levels, streamflow, and boundary conditions. Therefore, the results presented here should be interpreted with some caution.

\section{Effects of Full and Partial Shutdown of the Two Industrial Well Fields in North Olean and Along Allegheny River}

At present, all nitrogen-bearing ground water within the 0lean Nitrogen Complex is being captured by production wells of the oil company and by the purge well operated by the fertilizer company. If some or all these production wells we re shut down simultaneously, the present pattern of flow would gradually shift until a new hydraulic gradient developed, which would cause the nitrogen-bearing ground water to migrate southward and southwestward from the nitrogen complex to nearby private and municipal supply wells.

\section{Full shutdown}

Most of the experiments described herein were steady-state simulations, which produce an equilibrium response and maximum water-level and streamf low changes that would result from the hydrologic conditions simulated because no water is derived from storage. In reality, release from storage will cause a certain amount of time to elapse after pumping stops before these equilibrium conditions are reached. To evaluate the amount of time required before steady-state conditions are reached, a series of transient-state simulations were run that represented a full shutdown of the oil company's well fields. Different combinations of specific yield (1ayer 1) and storage coefficient (1ayer 2) ranging from 0.15 to 0.015 were simulated. These simulations provide some measure of the model's sensitivity to specific yield and storage coefficient over the range that may be applicable to the aquifer system.

Simulated curves of water-level recovery in an area near the fertilizer company's purge well ( $f$ ig. 7 ) show that water levels recover to steady-state values after about 0.6 year with a specific yield (laye 1 ) and a storage coefficient (layer 2) of 0.015 . (See fig. 7.) With a specific yield of 0.15 for layer 1 and a storage coefficient of 0.015 for layer 2 , water levels take almost 3 years before reaching steady-state recovery and, at values of 0.15 for both 1 ayers, they recover to about 95 percent of steady-state levels after 3 years. In the latter simulation, the storage coefficient used for 1 aye 2 is probably not representative because layer 2 is not dewatered under full pumping conditions. 
These simulations suggest that water-level recovery from a full shutdown should be complete some time between 1 and 3 yrs if the actual rate of recharge during shutdown is about the same as the simulated value of $19 \mathrm{in} / \mathrm{yr}$. Actual rates of recovery after a shut down can vary, however, because recharge $r$ ates deviate considerably from the average recharge used in the simulations.

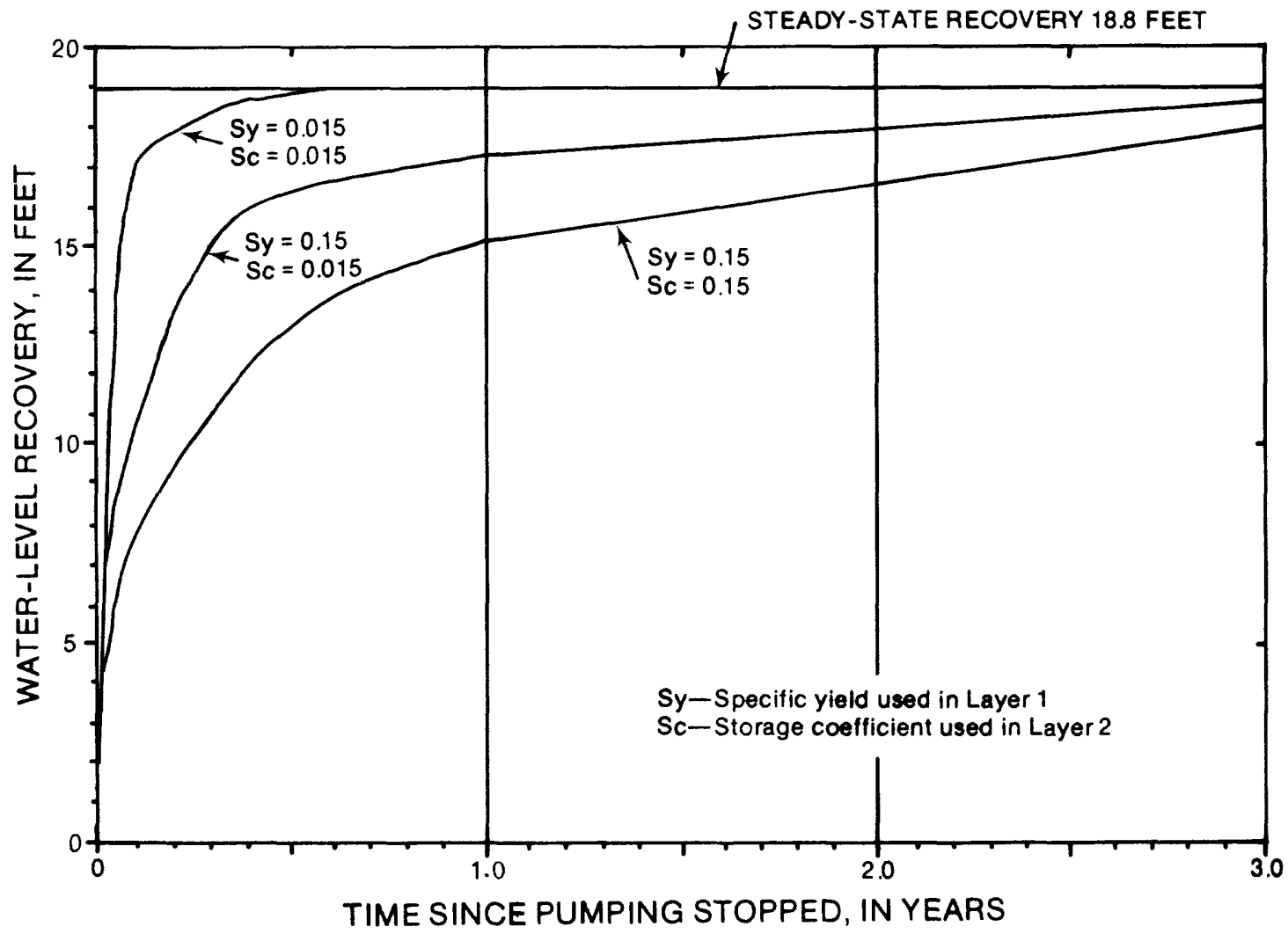

Figure 7.--Simulated water-level recovery after full shutdown of oil company wells in North olean, at two magnitudes of specific yield and storage coefficient.

To illustrate the effect of a full shutdown of the ofl company's wells and the fertilizer company's purge well, model-generated water levels in 1 ayer 2 are shown in plate 10 . Comparison of these water levels with the mode1generated steady-state level (pl. 8) indicate that water levels would rise 15 to $19 \mathrm{ft}$ after full shutdown near the nitrogen complex. Ground water that is now drawn toward the well field at the industrial park would flow south and southwestward after recovery. In this experiment, water levels at the model boundary at the 0lean Creek valley increased 1.5 to $1.9 \mathrm{ft}$ above the constanthead values used in the steady-state calibration run. An additional simulation that used constant heads from calibration was made to determine whether constant-flux values were significantly affected by recovery. In general, water-level recovery in the constant-head simulation was slightly less ( 0.1 to $0.2 \mathrm{ft}$ ) than recovery derived from the constant-flux simulation, which suggests that the boundary conditions we re not significantly affecting model results. 
After a full shutdown, nitrogen-bearing ground water would probably migrate southward to southwestward toward the Allegheny River, the direction of ground-water flow, as illustrated in plate 10. A calculation based on Darcy's 1aw, with the simulated hydraulic gradient, a hydraulic conductivity of about $1,000 \mathrm{ft} / \mathrm{d}$, and a porosity of 0.25 indicates that once steady-state conditions are attained, ground water migrating from the nitrogen complex would take about 5 years to reach the City of olean municipal (St. Francis) we 11 field along the Al legheny River. With a higher value of hydraulic conductivity and a lower value of porosity, the calculated arrival tine would be less. A hydraulic conductivity of $1,500 \mathrm{ft} / \mathrm{d}$ and a porosity of 0.15 results in an arrival time of 2.5 years.

Nitrogen concentrations of ground water arriving at the municipal well field would probably be reduced below the current levels at the industrial park through dilution, mechanical dispersion, and presumably adsorption. However, the exact effect of the fe factors on concentrations with distance of travel cannot be calculated at present; this would require use of an appropriate solute transport model, which was beyond the scope of this study.

\section{Partial Shutdown}

Partial shut down of the oil company's we 1 ss 1,2 , and 6 as well as the fertilizer company's purge well at the industrial park we re simulated in three modeling experiments. These wells were selected because they now capture about 98 percent of nitrogen being removed by pumping at the nitrogen complex. They would likely be selected for continued pumping for containment of ground water if a reduced pumping $\mathrm{pl}$ an we re developed. The experiments, designated $A, B$, and $C$, simulated three pumping plans. Experiment $A$ is a simulated pumping from all four we $11 \mathrm{~s}$; experiment $B$ is a simulated pumping from only wells 1,2 , and 6 , and experiment $C$ is a simulated pumping from only the fertilizer company's purge well.

The effect of partial-shutdown experiments $A, B$, and $C$, are shown in plates 11-13 as water-level distributions in layer 2. Comparison of these water levels with the steady-state levels ( $p 1.8$ ) indicates a water-level recovery of 6 to $8 \mathrm{ft}$ in experiment $A$, of 8 to $10 \mathrm{ft}$ in experiment $B$, and of. 14 to $16 \mathrm{ft}$ in experiment $C$. Even at these levels of recovery, the remaining cone of depression would contain at least a part of the nitrogen-bearing water within the industrial park. Additional simulations of the same experiments but with constant heads suggested that boundary conditions being used did not significantly affect model results.

Experiment A.--With the three production wells and the fertilizer company's purge well in use ( 1 1. 11), all nitrogen-bearing ground water is isolated in the cone of depression. Nitrogen concentrations in discharges from these wells may be slightly higher than those when alli other production we 11 s are in use because the nitrogen-bearing water would be withdrawn at a reduced rate, enabling the nitrogen to become more concentrated. This result might be less apparent in wells 1,2 , and 6 because they would draw additional "Olean" water that would normally be drawn to wells 3,4 , and 5. 
Experiment B.--With only we $11 \mathrm{~s} 1,2$, and 6 in use (p1.12), all nitrogenbearing water would also be contained in a resultant cone of depression. As in experiment $A$, nitrogen concentrations in we 11 discharges might be higher than concentrations derived when all production wells are in use.

Experiment C.-With only the purge well in use (pl.13), nitrogen-bearing ground water would escape along the southwest edge of the industrial park. Calculation of the migration rate of nitrogen-bearing ground water, based on Darcy's Law, an average simulated hydraulic conductivity of about $1,000 \mathrm{ft} / \mathrm{d}$, a porosity of 0.25 , and the simulated gradient, indicates that once steadystate conditions are attained, ground water flowing laterally from the nitrogen complex would take 8 to 9 years before reaching the city of olean municipal well field along the Allegheny River ( 1 1. 3).

As in the ful1-shutdown experiment A, nitrogen concentrations in the municipal we11-field discharge would probably be well below levels found at the nitrogen complex as a result of dilution, mechanical dispersion, ion exchange, and adsorption.

\section{Effects of Well-Shutdown Experiments on Streamflow}

\section{Full Shutdown}

A comparison of preshutdown water-budget values with those after full recovery from full shutdown (table 6) indicates a significant increase in the

Table 6.-Water budget for calibrated steady-state model and model experiments. [We11 locations shown in pl. 1; all values are in $\mathrm{ft}^{3} / \mathrm{s}$. ]

\begin{tabular}{|c|c|c|c|c|c|c|}
\hline \multirow[b]{2}{*}{ Model runs } & \multicolumn{3}{|c|}{ Inflows } & \multicolumn{3}{|c|}{ Discharges } \\
\hline & $\begin{array}{l}\text { Areal } \\
\text { recharge } \\
\text { from } \\
\text { precipi- } \\
\text { tation } \\
\end{array}$ & $\begin{array}{l}\text { Boun- } \\
\text { daries }\end{array}$ & $\begin{array}{l}\text { Seepage } \\
\text { from } \\
\text { streams }\end{array}$ & Pumpage & $\begin{array}{l}\text { Boun- } \\
\text { daries }\end{array}$ & $\begin{array}{c}\text { Seepage } \\
\text { to } \\
\text { streams }\end{array}$ \\
\hline $\begin{array}{l}\text { Calibrated run } \\
\text { Pumping experiments }\end{array}$ & 11.61 & 1.74 & 14.38 & 24.46 & 0.34 & 2.98 \\
\hline $\begin{array}{l}\text { Full shutd own } \\
\text { Partial s hutdown } 1\end{array}$ & 11.61 & 1.74 & .40 & 6.18 & .34 & 8.96 \\
\hline $\begin{array}{l}\text { Experiment A } \\
\text { Experiment } B \\
\text { Experiment } C\end{array}$ & $\begin{array}{l}11.61 \\
11.61 \\
11.61\end{array}$ & $\begin{array}{l}1.74 \\
1.74 \\
1.74\end{array}$ & $\begin{array}{l}1.85 \\
1.37 \\
1.01\end{array}$ & $\begin{array}{r}10.01 \\
8.79 \\
7.39\end{array}$ & $\begin{array}{l}.34 \\
.34 \\
.34\end{array}$ & $\begin{array}{l}6.67 \\
7.44 \\
8.35\end{array}$ \\
\hline $\begin{array}{l}\text { Re location of industrial } \\
\text { discharge from Twomile } \\
\text { Creek to Allegheny River }\end{array}$ & 11.61 & 1.74 & 14.28 & 24.46 & .34 & 2.88 \\
\hline
\end{tabular}

1 Experiment A entails continued operation of the oil company's production wells 1,2 , and 6 and the fertilizer company's purge well. Experiment B entails continued operation of the oil company's production wells 1,2 and 6 .

Experiment $C$ entails continued operation of the fertilizer company's purge well. 
amount of water flowing to streams. This is attributed partly to a decrease in induced infiltration and partly to water-leve 1 recovery. Data on seepage after a full shutdown are included in table 7. The difference in seepage rates generated by the calibrated model for present conditions and those resulting from the full-shutdown experiment indicates that flows to the Al legheny River, 01 ean Creek, and Twomile Creek would be increased by 16.6 , 1.6 , and $0.7 \mathrm{ft}^{3} / \mathrm{s}$, respectively.

\section{Partial shutdown}

The decrease in pumping that would result from partial shutdown (experiments $A, B$, and $C$ ) would also cause streamflow of the Allegheny River, 0lean Creek, and Twomile Creek to increase. The resulting seepage to the modeled stream reaches is summarized in table 6. These data indicate that flow in the Al legheny River, 0lean Creek, and Twomile Creek would increase from present steady-state conditions by $14.6,1.3$, and $0.12 \mathrm{ft}^{3} / \mathrm{s}$ in experiment $A$, by 16.3 , 1.7 , and $0.14 \mathrm{ft}^{3} / \mathrm{s}$ in experiment $B$, and by $17.5,2.5$, and $0.16 \mathrm{ft}^{3} / \mathrm{s}$ in experiment $C$.

Table 7.--Model-generated seepage rates under present conditions, four pumping schemes, and relocation of industrial discharge.

[AIl values are in $\mathrm{ft}^{3} / \mathrm{s}$. Positive values indicate seepage from stream to aquifer; negative signs indicate seepage from aquifer to stream. Locations are shown on plate 4.]

\begin{tabular}{|c|c|c|c|c|c|c|c|}
\hline \multirow{2}{*}{ Stream name } & \multirow{2}{*}{ Reach } & \multirow[b]{2}{*}{$\begin{array}{c}\text { Present } \\
\text { conditions }\end{array}$} & \multicolumn{4}{|c|}{ Pumping scheme } & \multirow{2}{*}{$\begin{array}{l}\text { Relocation of } \\
\text { industrial dis- } \\
\text { charge from } \\
\text { Twomile Creek to } \\
\text { Allegheny River }\end{array}$} \\
\hline & & & $\begin{array}{c}\text { Full } \\
\text { shutdown }\end{array}$ & & $\frac{\text { ial shu }}{\text { B }}$ & $\frac{o w n^{1}}{c}$ & \\
\hline $\begin{array}{r}\text { Twoml le } \\
\text { Cr eek }\end{array}$ & $\begin{array}{l}\text { A } \\
\text { B } \\
\text { C } \\
\text { D } \\
\text { E }\end{array}$ & $\begin{array}{l}0.0 \\
.04 \\
.32 \\
.35 \\
.31\end{array}$ & $\begin{array}{r}0.0 \\
.0 \\
.0 \\
.18 \\
.15\end{array}$ & $\begin{array}{l}0.0 \\
.04 \\
.32 \\
.35 \\
.19\end{array}$ & $\begin{array}{l}0.0 \\
.04 \\
.32 \\
.35 \\
.17\end{array}$ & $\begin{array}{l}0.0 \\
.04 \\
.32 \\
.35 \\
.15\end{array}$ & $\begin{array}{r}0.0 \\
.0 \\
.0 \\
.18 \\
.31\end{array}$ \\
\hline $\begin{array}{l}\text { Olean } \\
\text { Creek }\end{array}$ & $\begin{array}{l}\text { F } \\
\text { G } \\
\text { H }\end{array}$ & $\begin{array}{r}.59 \\
.98 \\
-.53\end{array}$ & $\begin{array}{l}-.36 \\
-.20 \\
-.94\end{array}$ & $\begin{array}{l}-.40 \\
-.45 \\
-.74\end{array}$ & $\begin{array}{r}-.50 \\
.26 \\
-.81\end{array}$ & $\begin{array}{l}-.53 \\
-.07 \\
-.81\end{array}$ & $\begin{array}{r}.61 \\
1.00 \\
-.52\end{array}$ \\
\hline $\begin{array}{l}\text { Al legheny } \\
\text { River }\end{array}$ & $\begin{array}{l}\mathrm{I} \\
\mathrm{J} \\
\mathrm{K}\end{array}$ & $\begin{array}{r}-.98 \\
.88 \\
10.14\end{array}$ & $\begin{array}{l}-1.07 \\
-1.06 \\
-4.45\end{array}$ & $\begin{array}{r}-1.04 \\
-.50 \\
-3.96\end{array}$ & $\begin{array}{r}-1.05 \\
-.75 \\
-4.46\end{array}$ & $\begin{array}{r}-1.74 \\
-.94 \\
4.77\end{array}$ & $\begin{array}{r}-.98 \\
.99 \\
10.47\end{array}$ \\
\hline
\end{tabular}

1 Experiment A entatls continued operation of the oil company's production wells 1,2 , and 6 and the fertilizer company's purge we 11 .

Experiment B entails continued operation of the ofl company's production wells 1,2 and 6 .

Experiment $C$ entails continued operation of the fertilizer company's purge we11. 


\section{Effects of Relocating Industrial Discharge from Twomile Creek}

Water now withdrawn from wells 1,2 , and 6 and from the purge well is used by the fertilizer company as cooling and process water. Because water from these wells contains about 98 percent of the nitrogen removed from the aquifer system at the well field, these wells provide the primary mechanism for containment and removal of the nitrogen-bearing ground water.

The pumped process and cooling water, which amounts to about $6 \mathrm{Mgal} / \mathrm{d}$, is discharged to Twomile Creek after use. The discharge has ammonia concentrations ranging from 10 to $15 \mathrm{mg} / \mathrm{L}$, nitrate concentrations ranging from 2 to 10 $\mathrm{mg} / \mathrm{L}, \mathrm{pH}$ ranging from 6.8 and 7.4 , and temperatures ranging from 75 to $85^{\circ} \mathrm{F}$. This discharge transforms the stream from an ephemeral type to one with substantial year-round flow and the ability to support some fish and other aquatic life. However, State laws require that the maximum total ammonia concentration in discharge to Two Mile Creek not exceed $2.0 \mathrm{mg} / \mathrm{L}$. A proposed alternative would entail relocation of the discharge point to the Allegheny River, where higher flows can assimilate the high ammonia concentrations. The hydrologic effects could be that Twomile Creek would return to its intermittent nature and perhaps have little or no flow during dry weather. Because Twomile Creek flows across the cone of depression created by the olean industrial park and provides about $1.0 \mathrm{ft} / \mathrm{s}$ of induced infiltration, relocation of discharge would alter patterns of ground-water flow and al so would decrease ground-water recharge, ground-water levels, and ground-water seepage to the Allegheny River and Olean Creek.

The relocation was simulated to evaluate the hydrologic effects. Pumping at the industrial park nitrogen complex well field was held at current rates, but the induced infiltration from Twomile Creek to the aquifer system was eliminated. The Allegheny River stage was simulated as in the calibrated steady-state run because the industrial discharge of $6 \mathrm{Mgal} / \mathrm{d}$ is small in comparison to the base flow in the Allegheny River, which commonly ranges from 130 to $190 \mathrm{Mgal} / \mathrm{d}$, and its effect on stage would be insignificant.

The potentiometric surface in layer 2 that would result from the simulation of discharge relocation is shown in plate 14. The water-1evel contours indicate that the full-scale pumping used in this simulation causes a large cone of depression that is similar to the present one indicated by the calibrated model (p1. 8). Despite the loss of induced infiltration, all nitrogenbearing ground water will still be isolated and will be removed by pumping at the well field. Because Twomile Creek provides no recharge to the aquifer except in lower reaches ( $D$ and $E$ ), water levels would decline an additional 1 to $3 \mathrm{ft}$ near Twomile Creek west of the pumping wells, causing additional induced recharge along the Al legheny River and from olean Creek. Comparison of the present seepage rates indicated by the calibrated model with the rates after discharge relocation, given in table 6 , indicates that streamf low in the Al legheny River and 0lean Creek would be reduced by 0.45 and $0.05 \mathrm{ft} / \mathrm{s}$, respectively. Reaches $D$ and $E$ of Twomile Creek would continue to contribute 0.18 and $0.31 \mathrm{ft} 3 / \mathrm{s}$ of recharge to the aquifer. 


\section{SUMMARY AND CONCLUSIONS}

A glacial outwash aquifer system in southeast Cattar augus County contains large amounts of nitrogen compounds beneath an industrial park in North olean. The nitrogen compounds were introduced into the aquifer by operations of a local fertilizer plant. Pumping from seven production wells owned by an oil company and a purge well operated by the fertilizer company at the site create a cone of depression within which the nitrogen compounds are contained and thus prevented from migrating to nearby public, private, and industrial supply wells. Water from the oil company's production wells 1,2 , and 6 and the fertilizer company's purge well contain about 98 percent of the nitrogen removed from the well field. Ground water within the cone of depression contains nitrogen concentrations ranging from 10 to $2,000 \mathrm{mg} / \mathrm{L}$.

The aquifer system consists of extensive unconsolidated outwash deposits that are composed primarily of coarse sand and gravel. These deposits extend to less than $100 \mathrm{ft}$ below 1 and surface and are the only potential source for large amounts of ground water near olean. The ground-water system contains two aquifers--a surficial water-table aquifer of variable thickness throughout the Olean area, and a deeper semiconfined aquifer that is locally separated from the surficial aquifer by impervious lake beds. At and near the industrial park, the aquifer system is about $80 \mathrm{ft}$ thick, but the lower $30 \mathrm{ft}$ is generally more permeable than the upper $50 \mathrm{ft}$, which contains siltier gravel. Thin lenses of silty clay occur locally between depths of 30 and $50 \mathrm{ft}$.

Hydraulic properties of the aquifer system were estimated from analyses of pumping-test data, specific-capacity data, and simple two-dimensional models. Transmissivity of the aquifer system commonly ranges from 10,000 to 60,000 $\mathrm{ft}^{2} / \mathrm{d}$. Hydraulic conductivity values commonly range from 250 to $750 \mathrm{ft} / \mathrm{d}$.

Normally, ground water would flow downvalley and toward the two principal streams--the Al legheny River and Olean Creek. However, ground-water withdrawals at several pumping centers, most notably at the industrial park, have altered this pattern of flow locally.

A quasi-three-dimensional ground-water flow model consisting of two aquifer layers was used to simulate flow within the aquifer system. Steadystate calibration of the model to average 1981 hydrologic conditions showed that precipitation, underflow at upval ley model boundaries, and induced infiltration from streams account for 42, 6, and 52 percent of recharge to the simulated area, respectively. Ground-water wi thdrawals, underflow at downvalley model boundaries, and seepage to streams represent 88,1 , and 11 percent of the discharge from the system.

A full shutdown of all the oil company's production wells and the fertilizer company's purge well would increase water levels and cause flows of Al legheny River, Ol ean Creek, and Twomile Creek to increase by 16.6, 1.6 and $0.7 \mathrm{ft} / \mathrm{s}$. The increased water levels would cause the nitrogen-bearing ground water to migrate south southwestward downvalley and toward the Allegheny River. After steady state is attained, the traveltime of ground water moving from the nitrogen complex to the municipal well field in southwest olean would be about 5 years. Nitrogen concentrations in ground water arriving at the well field should be significantly lower than present concentrations in North olean as a result of dilution, mechanical dispersion, and adsorption. 
Shutdown of all the ofl company's production wells at the site except wells 1,2 , and 6 and the fertilizer company's purge well (experiment A) would maintain a cone of depression adequate to contain all nitrogen-bearing ground water. Pumping only wells 1,2 , and 6 (experiment B) would also contain nitrogenbearing ground water within a cone of depression. Pumping only the purge well (experiment C) would allow nitrogen-bearing ground water to escape. Trave1time to the municipal well field under this condition would be about 8 years.

Reduced pumping would raise ground-water levels and increase seepage to Allegheny River, Olean Creek, and Twomile Creek. The predicted increase in streamf low from present steady-state conditions in experiment A are 14.6, 1.3, and $0.12 \mathrm{ft}^{3} / \mathrm{s}$; those in experiment $B$ are $16.3,1.7$, and $0.14 \mathrm{ft}^{3} / \mathrm{s}$; those in experiment $\mathrm{C}$ are $17.5,2.5$, and $0.16 \mathrm{ft}^{3} / \mathrm{s}$. Relocating the discharge of industrial cooling water from Twomile Creek to Allegheny River would cause ground-water levels near Twomile Creek to decline 1 to $3 \mathrm{ft}$ bel ow present steady-state levels, but all nitrogen-bearing ground water would still be held within the cone of depression in the 0lean nitrogen complex well field. Relocation of the industrial discharge would stop the present induced infiltration from Twomile Creek and would decrease streamflow in Allegheny River and 0lean Creek by only 0.45 and $0.05 \mathrm{ft}^{3} / \mathrm{s}$.

\section{REFERENCES CITED}

Brown, R. H., 1963, Estimating the transmissibility of an artesian aquifer from the specific capacity of a well, in Benta11, Ray, Methods of determing permeability, tranmissibility, and drawd own: U.S. Geological Survey Water-Supply Paper 1536-I, D. I336-I338.

Ferris, J. G., Knowles, D. B., Brown, R. H., and Stallman, R. W., 1962, Theory of aquifer tests: U.S. Geological Survey Water-Supply Paper 1536-E, 105 p.

Frimpter, M. H., 1974, Ground-water resources, Allegheny River basin and part of the Lake Erie basin, New York: New York St ate Department of Envi ronmental Conservation, Basin Planning Report ARB-2, 97 p.

Harding, W. E., and Gi 1bert, B. K., 1968, Surface Water in the Erie-Niagara Basin, New York: State of New York Conservation Department, Water Resources Commission, Basin Planning Report ENB-2, 118 p.

Hydro Systems, Inc., 1974, Progress report to C. F. Industries, Inc., 0lean nitrogen complex, ground-water pollution problem: Lawrence, Kansas, Hydro Systems, Inc., $70 \mathrm{p}$.

1975, Analysis of the ground-water pollution problem at Agway, Inc., Olean nitrogen complex, Olean, N.Y.: Lawr ence, Kansas, Hyd ro Systems, Inc., $114 \mathrm{p}$.

1976, Progress report, analys is of the ground-water pollution problen at Agway, Inc., Olean nitrogen complex, 0lean, N.Y.: Lawrence, Kansas, Hyd ro Sys tems, Inc., 45 p. 